University of Nebraska - Lincoln

DigitalCommons@University of Nebraska - Lincoln

\title{
STABLE ISOTOPES IN OBESITY RESEARCH
}

\author{
Gregory G. Dolnikowski \\ Jean Mayer USDA Human Nutrition Center, gregory.dolnikowski@tufts.edu \\ Julian B. Marsh \\ Jean Mayer USDA Human Nutrition Center \\ Sai Krupa Das \\ Jean Mayer USDA Human Nutrition Center \\ Francine K. Welty \\ Jean Mayer USDA Human Nutrition Center
}

Follow this and additional works at: https://digitalcommons.unl.edu/usdaarsfacpub

Dolnikowski, Gregory G.; Marsh, Julian B.; Das, Sai Krupa; and Welty, Francine K., "STABLE ISOTOPES IN OBESITY RESEARCH" (2005). Publications from USDA-ARS / UNL Faculty. 1434.

https://digitalcommons.unl.edu/usdaarsfacpub/1434

This Article is brought to you for free and open access by the U.S. Department of Agriculture: Agricultural Research Service, Lincoln, Nebraska at DigitalCommons@University of Nebraska - Lincoln. It has been accepted for inclusion in Publications from USDA-ARS / UNL Faculty by an authorized administrator of DigitalCommons@University of Nebraska - Lincoln. 


\title{
STABLE ISOTOPES IN OBESITY RESEARCH
}

\author{
Gregory G. Dolnikowski, * Julian B. Marsh, Sai Krupa Das, and Francine K. Welty \\ Jean Mayer USDA Human Nutrition Center on Aging at Tufts University, \\ 711 Washington Street, Boston, Massachusetts 02111 \\ Received 29 April 2003; received (revised) 25 February 2004; accepted 26 February 2004 \\ Published online in Wiley InterScience (www.interscience.wiley.com) DOI 10.1002/mas.20021
}

\begin{abstract}
Obesity is recognized as a major public health problem. Obesity is a multifactorial disease and is often associated with a wide range of comorbidities including hypertension, non-insulin dependent (Type II) diabetes mellitus, and cardiovascular disease, all of which contribute to morbidity and mortality. This review deals with stable isotope mass spectrometric methods and the application of stable isotopes to metabolic studies of obesity. Body composition and total energy expenditure (TEE) can be measured by mass spectrometry using stable isotope labeled water, and the metabolism of protein, lipid, and carbohydrate can be measured using appropriate labeled tracer molecules.

(C) 2004 Wiley Periodicals, Inc., Mass Spec Rev 24:311-327, 2005
\end{abstract}

Keywords: stable isotopes; obesity; metabolism

\section{INTRODUCTION}

Obesity is recognized as a major public health problem, not only in those parts of the world where food supply is amply available and affordable but also in developing countries (WHO, 1997; Popkin \& Doak, 1998; Hoffman et al., 2000; Flegal et al., 2002). The World Health Organization defines overweight and obesity using cut points of body mass index (BMI, $\mathrm{kg}$ body weight $/ \mathrm{m}^{2}$ body height). A BMI between 25 and $30 \mathrm{~kg} / \mathrm{m}^{2}$ is defined as overweight and obesity is defined by BMI $=30 \mathrm{~kg} / \mathrm{m}^{2}$ (WHO, 1995). Using BMI cut points, obesity is further classified into mild (BMI 30-34.9 kg/m²), moderate (BMI 35-39.9 kg/m ${ }^{2}$ ), and extreme $\left(\mathrm{BMI}=40 \mathrm{~kg} / \mathrm{m}^{2}\right)$ categories. In 1988-1994 NHANES III determined that the prevalence of overweight in individuals in the United States over the age of 18 was $55.9 \%$, and the prevalence of obesity was $22.9 \%$. In 1999-2000, the prevalence of overweight was $64.5 \%$ and obesity was $30.5 \%$ (Flegal et al., 2002). Obesity is also increasingly a problem in children, and it is known that half of all obese children become obese adults (Serdula et al., 1993).

Obesity is a multifactorial disease and is often associated with a wide range of comorbidities including hypertension, noninsulin dependent (Type II) diabetes mellitus, and cardiovascular disease, all of which contribute to morbidity and mortality (Van Itallie, 1985; National Vital Statistics Report, 2002). In the development of obesity, energy storage as fat occurs because energy intake (EI) significantly exceeds total energy expenditure (TEE) as heat and work, until a new steady state is reached with intake equaling expenditure at a higher level of body fat. Research in obesity includes studies exploring the mechanisms of

*Correspondence to: Gregory G. Dolnikowski, Jean Mayer USDA Human Nutrition Center on Aging at Tufts University, 711 Washington Street, Boston, MA 02111. E-mail: gregory.dolnikowski@tufts.edu hunger control; the regulation of whole body energy production, utilization, and storage; the regulatory roles of the neuroendocrine, central, and sympathetic nervous systems; and the tissues, especially the liver and the adipose tissue itself (Bachman et al., 2002; Dulloo, 2002).

Stable isotopes have been employed in the measurement of the synthesis and catabolism of virtually every class of organic molecules, whether in the whole body, or in cell culture or cellfree systems. Although many advances have been made in research on obesity in animal models, many of these studies used radioisotopes. Unlike radioisotopes, stable isotopes are safe to administer to humans and are particularly applicable to human research studies of obesity.

Using stable isotope mass spectrometry, the following measures can be obtained: (1) body composition analysis, using total body water (TBW) assessment using deuterium $\left({ }^{2} \mathrm{H}\right)$ or oxygen $18\left({ }^{18} \mathrm{O}\right)$; (2) energy expenditure measurement using doubly-labeled water $\left({ }^{2} \mathrm{H}^{18} \mathrm{O}\right)$ estimates of carbon dioxide production and hence TEE; (3) turnover of biopolymers, including nucleic acids, proteins, lipids, and carbohydrates, using infused labeled precursors; (4) estimation of synthetic and catabolic rates of proteins and other molecules in the circulation using bolus or primed constant infusions of stable isotope labeled precursors; (5) absorption and excretion using isotope labeling to follow the metabolism of dietary micronutrients such as vitamins or inorganic metals.

Computer programs for multicompartmental analysis of the data have facilitated kinetic studies of nutrient metabolism. The present review deals with stable isotope mass spectrometric methods and the application of stable isotopes to metabolic studies of obesity. Because of the association of obesity with other diseases, this review also includes studies not primarily directed to obesity but which are nevertheless pertinent. For more general reviews of obesity research, journals such as Obesity Reviews and the International Journal of Obesity may be consulted. A review on stable isotope ratio mass spectrometers can be found in Mass Spectrometry Reviews (Brenna et al., 1997), and a symposium on obesity has been published (Cavagnini et al., 2002).

\section{METHODOLOGY}

\section{A. Introduction}

Mass spectrometers are extremely important analytical instruments in many fields and are rapidly becoming indispensable in biological research. John B. Fenn and Koichi Tanaka won the 2002 Nobel Prize in Chemistry "for their development of soft desorption ionisation methods for mass spectrometric analyses of 
biological macromolecules." Nevertheless, they are not a recent invention. The first mass spectrometer was built beginning in 1905 (Thomson, 1913). More complex instruments were built shortly thereafter (Dempster, 1918; Aston, 1919). They both observed that neon consisted of two masses, not one, and Aston concluded that the higher mass was because of a stable isotope (Thomson, 1921; Aston, 1942). Nier built a mass spectrometer specifically designed for measuring isotope ratios with high precision (Nier, 1947).

\section{B. Isotope Ratio Mass Spectrometry (IRMS)}

Today, instruments used for high-precision IRMS consist of three parts. The first is an electron ionization source for producing ions from $\mathrm{CO}_{2}, \mathrm{H}_{2}, \mathrm{~N}_{2}$, or $\mathrm{SO}_{2}$. The second is a single sector magnet for separating the isotopomers of these ions. The third is an array of faraday cup detectors for detecting simultaneously all of the isotopomers of a given molecular ion. All other compounds that one might wish to study must be converted to $\mathrm{CO}_{2}, \mathrm{H}_{2}, \mathrm{~N}_{2}$, or $\mathrm{SO}_{2}$, if one wishes to measure their isotopic composition. The ultimate in high precision may be achieved using a dual inlet ion source (Brand, 1996) in which a sample and a standard are alternately measured at the same ion source pressure. Alternatively, one may sacrifice some precision, but dramatically increase sample throughput by using a continuous flow inlet (Brenna et al., 1997) connected to a gas chromatograph or other gas-sampling device.

Gas IRMS instruments used for obesity research measure the following isotope ratios: ${ }^{2} \mathrm{H} /{ }^{1} \mathrm{H},{ }^{13} \mathrm{C} /{ }^{12} \mathrm{C},{ }^{18} \mathrm{O} /{ }^{16} \mathrm{O}$. Isotope ratios for heavier elements can be measured by IRMS using different ion sources, but these have not been employed to date for obesity research. The common isotope ratios measured for obesity research are $(1){ }^{1} \mathrm{H} /{ }^{2} \mathrm{H}$, and ${ }^{16} \mathrm{O} /{ }^{18} \mathrm{O}$ for doubly labeled water (DLW) measurement of TEE, (2) ${ }^{1} \mathrm{H} /{ }^{2} \mathrm{H}$ or ${ }^{16} \mathrm{O} /{ }^{18} \mathrm{O}$ for TBW determination, and $(3){ }^{12} \mathrm{C} /{ }^{13} \mathrm{C}$ for breath test determinations of $\mathrm{CO}_{2}$ metabolism from metabolic precursors.

To maximize precision in IRMS, isotope ratios of samples are compared to standard isotope ratios (Gonfiantini, 1978). Data are expressed as unitless delta values per mil (\%o) with respect to the standard (Wong \& Klein, 1986).

$$
\left(\left(\mathrm{R}_{\text {sample }}-\mathrm{R}_{\text {standard }}\right) / \mathrm{R}_{\text {standard }}\right) \times 1,000=\text { delta }
$$

The international standard for ${ }^{1} \mathrm{H} /{ }^{2} \mathrm{H}$, and ${ }^{16} \mathrm{O} /{ }^{18} \mathrm{O}$ is Vienna Standard Mean Ocean Water (VSMOW) (Coplen, 1988) and for ${ }^{12} \mathrm{C} /{ }^{13} \mathrm{C}$ Vienna Pee Dee Belemnite (VPDB) (McCrea, 1950). These reference standards available from the International Atomic Energy Agency are in short supply, so IRMS laboratories manufacture their own working standards and calibrate their values relative to the international standards. Table 1 (May \& Rumble, 2001) shows the isotope ratios, precisions, and delta values for VSMOW and for Standard Light Arctic precipitation (SLAP), another standard that is defined relative to VSMOW.

${ }^{13} \mathrm{C} /{ }^{12} \mathrm{C}$ isotope ratios are defined relative to those of carbon dioxide formed from Pee Dee Belemnite (calcium carbonate) by $100 \%$ phosphoric acid at room temperature (Craig, 1953), which had an isotope ratio of $1,1237 \times 10^{-6}$. PDB is no longer available, but a hypothetical new standard, VPDB, has been defined by international agreement. The calcium carbonate standard
TABLE 1. Isotope ratios and deltas for standards VSMOW and SLAP

\begin{tabular}{lccc}
\hline Standard & $\begin{array}{c}\text { Isotope } \\
\text { ratio }\end{array}$ & $\begin{array}{c}\text { Std. } \\
\text { Dev. }\end{array}$ & $\begin{array}{c}\text { Delta vs. } \\
\text { VSMOW }\end{array}$ \\
\hline${ }^{2} \mathrm{H} /{ }^{1} \mathrm{H}$ VSMOW & 155.76 & 0.05 & 0 \\
${ }^{2} \mathrm{H} /{ }^{1} \mathrm{H}$ SLAP & 89.02 & 0.05 & -428.0 \\
${ }^{18} \mathrm{O} /{ }^{16} \mathrm{O}$ VSMOW & 2005.2 & 0.45 & 0 \\
${ }^{18} \mathrm{O} /{ }^{16} \mathrm{O}$ SLAP & 1893.9 & 0.45 & -55.5 \\
\hline
\end{tabular}

NBS-19 has been defined as $1.95 \%$ relative to VPDB. Table 2 shows the ${ }^{13} \mathrm{C} /{ }^{12} \mathrm{C}$ deltas and precisions for the newly available calcium carbonate international standards IAEA-CO-1 and IAEA-CO-8 (IAEA-TECDOC-825, 1993).

Because the delta values (10-500\%) of the enriched biological samples related to obesity are commonly much higher than the enrichments of the international standards which were developed for geological research, it is critical for each IRMS laboratory to have high enrichment standards (Roberts et al., 1995). Unfortunately no internationally recognized high enrichment standards designed for obesity research have yet been developed.

Because all compounds of interest must be converted to $\mathrm{H}_{2}$ or $\mathrm{CO}_{2}$ for measurement by IRMS, sample preparation techniques are critically important to the success of the measurement (Wong \& Klein, 1986). Nearly all obesity studies that employ ${ }^{18} \mathrm{O}$ as a tracer use an equilibration technique (Wong, Lee, \& Klein, 1987) to transfer the label from the water in a biological fluid to $\mathrm{CO}_{2}$ gas. A similar technique is also employed for ${ }^{2} \mathrm{H}$ (Horita, 1988). The biological fluid is equilibrated with $\mathrm{H}_{2}$ gas in the presence of platinum Hokko beads (Coplen, Wildman, \& Chen, 1991 ) or a $5 \%$ platinum on alumina catalyst (Prosser \& Scrimgeour, 1995; Thielecke \& Noack, 1997; Thielecke, Brand, \& Noack, 1998; Yao et al., 2002). There is a competing sample preparation technique for ${ }^{2} \mathrm{H}$, which requires the water in the biological fluid to be separated quantitatively by distillation, and then reduced to $\mathrm{H}_{2}$ gas by contact with a hot metal such as zinc (Wong et al., 1992; Schoeller et al., 2000), depleted uranium (Hopple, Hannon, \& Coplen, 1998) or chromium (Schoeller, Taylor, \& Shay, 1995). Recently the equilibration and reduction techniques have been compared and found to agree (Hopple, Hannon, \& Coplen, 1998; Sonko et al., 2003). ${ }^{13} \mathrm{C}$ analysis of $\mathrm{CO}_{2}$ in breath requires no sample preparation because the sample is already a gas.

TABLE 2. Deltas for standards IAEA-CO- 1 and IAEA-CO- 8

\begin{tabular}{lcc}
\hline Standard & Delta vs. VPDB & Std. Dev. \\
\hline${ }^{13} \mathrm{C} /{ }^{12} \mathrm{C}$ IAEA-CO-1 & 2.48 & 0.025 \\
${ }^{13} \mathrm{C}^{12} \mathrm{C}$ IAEA-CO-8 & -5.749 & 0.063 \\
\hline
\end{tabular}




\section{Gas Chromatography-Mass Spectrometry (GC-MS)}

The GC-MS interface was invented in the 1960's to provide a sensitive detector for the GC and to provide a sample introduction system for the MS (James, 1970; Ryhage, 1964; Watson \& Biemann, 1964). Samples injected into the GC are vaporized and separated by boiling point and by differential affinity for the stationary phase contained in a long column. Modern columns are predominately fused silica capillaries coated internally with a viscous liquid stationary phase (Grob, 1985). A carrier gas (typically helium) sweeps the separated compounds one by one into the MS, where they are ionized by electron ionization or one of many chemical ionization techniques. The ions thus formed, have been detected by numerous types of mass spectrometers (Watson, 1997; Ragunathan et al., 1999). Most current GC-MS applications for obesity research employ the quadrupole mass filter mass spectrometer with an electron multiplier detector, because it is relatively inexpensive, highly sensitive, highly automated, and easy to use.

GC-MS has been applied to quantitative analysis for many compounds of environmental and biological interest, using stable isotope labeled compounds as internal standards (Leis, Fauler, \& Windischhofer, 1998). However, the majority of obesity studies employ the GC-MS in the opposite manner to detect the presence of a stable isotope labeled compound. One administers the stable isotope labeled compound to the biological subject as a tracer (Pont et al., 1998) and then monitors the appearance of the tracer in the plasma or urine by GC-MS. The exact amount of the tracer is usually not the parameter of interest, but rather the ratio of the isotope labeled tracer to the unlabeled compound in the sample, and is sometimes expressed as the tracer-tracee ratio $(\mathrm{T} / \mathrm{t})$ and sometimes as percent enrichment.

$\mathrm{T} / \mathrm{t}=$ sum of labeled isotopomers' abundance/total abundance of all isotopomers

$\%$ Enrichment $=(\mathrm{T} / \mathrm{t}) \times 100$

Because the GC-MS usually uses a single detector (unlike the IRMS), the quadrupole MS must detect the various isotopomer ions in a repetitive sequence called selected ion monitoring (SIM) (Watson, 1997). GC-MS-SIM has the advantage that one can detect any ion from $\mathrm{m} / \mathrm{z} 10$ to 1,000 , and unlike the IRMS, it is not limited to only a few molecular ions. But it has the disadvantage that the dynamic range of the single detector limits the range of measurable isotope ratios. The IRMS employs multiple detectors so that nearly any isotope ratio could be measured. GC-MS and IRMS are thus complementary techniques. Sometimes both are used in different parts of a tracer study, e.g., in total-body protein turnover determinations (Wagenmakers, 1999).

\section{GC-C-IRMS}

Recently GC has been combined with IRMS using a combustion interface (Brenna et al., 1997). Compounds eluting from the GC are combusted in an on-line furnace to $\mathrm{H}_{2} \mathrm{O}$ and $\mathrm{CO}_{2}$. If the isotope label is ${ }^{13} \mathrm{C}$, the water is removed cryogenically or with a drying agent and the $\mathrm{CO}_{2}$ is analyzed directly by an IRMS. If the label is ${ }^{2} \mathrm{H}$, the water is reduced to $\mathrm{H}_{2}$ over hot chromium in a second on-line furnace and analyzed by IRMS. The GC-C-IRMS technique has the advantages of both GC-MS and IRMS in that it allows one to perform stable isotope analysis on complex mixtures including fatty acids (Meier-Augenstein, 2002), and prostaglandins and leukotrienes (Brenna, 1997) with the full precision and dynamic range of the IRMS. GC-C-IRMS has also been performed on $\beta$-carotene (Parker et al., 1997). No obesity studies have yet been performed on a GC-C-IRMS, since is still quite novel, complex, and very expensive, but it clearly represents the direction in which stable isotope tracer studies are headed.

\section{BODY COMPOSITION}

Obesity is a condition characterized by excess body fat. With increasing levels of overweight or obesity, there are increases in percent body fat, and changes in relative hydration of body water compartments. For example, changes in extra-cellular water (ECW), and intra-cellular water (ICW) are observed (Wong et al., 1989; Waki et al., 1991; Mazariegos et al., 1992; Das et al., 2003). To understand these changes, researchers have developed many approaches to measuring body composition (Ellis, 2000), including underwater weighing (Fogelholm \& Lichtenbelt, 1997), air displacement plethysmography (Dempster \& Aitkens, 1995; Fields, Goran, \& McCrory, 2002), dual photon X-ray absorptiometry (DXA) (Pietrobelli et al., 1996), magnetic resonance imaging (MRI) (Shen et al., 2003), bio-electrical impedance (DeLorenzo et al., 1997), total-body potassium (TBK) counter (Kehayias et al., 1997), and isotope dilution techniques (Schoeller et al., 1980; Wang et al., 1999). Some of these techniques measure two compartments of the body-fat mass (FM) and fat free mass - while other methods allow for further compartmentalization of body mass into body water, muscle mass, and skeletal mass. The most accurate approaches appear to be those that combine the results of several different methods that have complementary strengths (Wang, Pierson, \& Heymsfield, 1992; Albu et al., 1997; Forslund, 1998; Wang et al., 1998; Withers, Laforgia, \& Heymsfield, 1999), such that three or more compartmental models can be constructed, leading to a greater understanding of obesity or changes with weight gain or weight loss (Wang, Pierson, \& Heymsfield, 1992, 1998; Albu et al., 1997; Forslund, 1998; Withers, Laforgia, \& Heymsfield, 1999; Yao et al., 2002; Das et al., 2003).

The use of stable isotopes for the determination of TBW (Schoeller et al., 1980) has greatly helped in the understanding of body composition in obesity research. In particular, as a singlemethod technique it is accurate and can be used in field situations where instruments like DXA would not be feasible. When combined with other methods in a multicompartmental model it can be used to quantify both absolute body fat and the quality of lean body mass (e.g., hydration (Wang et al., 1999a,b)). The TBW technique employs IRMS for the detection of the enrichment of the stable isotope in the sample.

Practically speaking, isotope dilution technique is a simple method. The subject is dosed with isotopic water that is enriched in either ${ }^{18} \mathrm{O}$ or ${ }^{2} \mathrm{H}$ or both. Urine or blood samples are collected 
from the subject before and at timed intervals after the heavy water dose. Since the molar amount of isotope in the dose is known, the measured increase of the isotope in the subject's postdose sample allows one to calculate the total volume of body water into which the isotope was diluted. Although researchers have also used radioactive ${ }^{3} \mathrm{H}$ for this same determination (Roubenoff et al., 2000), stable isotopes have remained the preferred method of tagging molecules for studying metabolism in humans. ${ }^{18} \mathrm{O}$ and ${ }^{2} \mathrm{H}$ measurements of TBW by IRMS do not yield identical results, because the dilution spaces of these isotopes in the body are different. ${ }^{18} \mathrm{O}$ distributes primarily in body water, with the result that the dilution space closely approximates $\mathrm{TBW}$, whereas the ${ }^{2} \mathrm{H}$ space is on average approximately $3 \%$ greater. Formulas are available to convert both dilution spaces to TBW (Speakman, Nair, \& Goran, 1993; Racette et al., 1994). TBW determinations using $\mathrm{O}^{18}$ are often performed in concert with the DLW method (see below), for measuring energy expenditure. When energy expenditure is not measured and only TBW is desired, ${ }^{2} \mathrm{H}$ is the more commonly used stable isotope since it is very inexpensive compared to $\mathrm{O}^{18}$. Another method related to TBW determination is the bromide dilution technique for measuring ECW, (DeLorenzo et al., 1997). One can calculate ICW by subtracting ECW from TBW if the measurements are done from samples taken during the same time period. The bromide dilution technique does not involve the use of a mass spectrometer and is useful when further compartmentalization of TBW into ECW and ICW is required.

Longitudinal data indicate that TBW volume, on average, is reasonably stable in men and women through a large portion of adulthood (Chumlea et al., 1999). TBW measurements obtained using the isotope dilution technique can also be used to estimate fat and FFM as follows. An assumed constant (0.738) (Brozek et al., 1963) for the hydration factor of FFM is calculated by dividing TBW by FFM (TBW/FFM). Thus using the assumed value of 0.738 and the measured TBW, FFM and hence FM can be calculated (Baumgartner et al., 1991; Goran et al., 1994). While an assumed constant is a reasonable approximation for normal adult men and women, the assumption may not be valid in other physiological states such as childhood, old age, extreme obesity, or diseased conditions. Obesity in children, e.g., is associated with a highly significant relative expansion of ECW (Battistini et al., 1995) but not TBW. Extremely obese adults tend to have an expanded ECW compartment, causing TBW measurements by isotope dilution to overestimate FFM (Waki et al., 1991; Das et al., 2003).

TBW is positively associated with body weight, height, FM, and BMI in both sexes and in all races (Chumlea et al., 2001). TBW is the largest body compartment in normal weight individuals. But in moderate and extreme obesity, percent body fat increases greatly, resulting in a relatively smaller TBW compartment. Following conventional weight loss in the obese, large decreases in FM and relative shifts in body water compartments are observed (Gallagher et al., 2000), and similar changes have been reported following massive weight loss in the morbidly obese undergoing gastric bypass surgery (Das et al., 2003). The use of stable isotopes has greatly facilitated the accurate measurement of such changes with weight loss and in understanding these physiological states.

\section{ENERGY EXPENDITURE}

Positive energy balance leads to excess weight gain. Positive energy balance can occur when energy expenditure is low or when EI is high, or by a combination of these two factors. The measurement of EI is rather difficult and imprecise because EI is highly variable, and also because most techniques rely on the individual's ability to report or recall the amount of food eaten. Further, most individuals underreport, and the degree of underreporting is known to increase with increasing adiposity (Schoeller, 1990; Schoeller, Bandini, \& Dietz, 1990).

The measurement of energy expenditure by indirect calorimetry is relatively more reliable and accurate. Indirect calorimetry involves the measurement of respiratory gas exchange-oxygen uptake and carbon dioxide output—while a subject is confined to a bed or a small room. The respiratory gas exchange values can in turn be converted to energy equivalents over a 24-hr period. In a weight stable subject, if the change in body energy stores $(\triangle \mathrm{BES})$ are known, then energy expenditure plus change in body energy stores is equivalent to EI.

$$
\mathrm{EI}=\mathrm{EE}+\Delta \mathrm{BES} \text {. }
$$

The DLW method, which uses two stable isotopes: ${ }^{2} \mathrm{H}$ and ${ }^{18} \mathrm{O}$, (Schoeller \& Vansanten, 1982) can be considered a way of performing indirect calorimetry in free-living individuals. Unlike traditional indirect calorimetry, which requires a subject to be confined, the DLW method allows for measurement of energy expenditure while subjects are leading their usual daily lives. The subject's urine (or serum) is collected to assess baseline abundances of ${ }^{2} \mathrm{H}$ and ${ }^{18} \mathrm{O}$, and the subject then drinks a dose of water that has been labeled with both ${ }^{2} \mathrm{H}$ and ${ }^{18} \mathrm{O}$. Urine is collected from the subject periodically over the course of 2 weeks, and each urine sample is analyzed twice by IRMS, once for ${ }^{2} \mathrm{H}$ and once for ${ }^{18} \mathrm{O}$.

Figure 1 shows that there is a rapid rise in both isotopes following the dose while the isotopes equilibrate with the body water. Then there is a slow exponential decline in both isotopes as the isotopes are cleared from the body, primarily through water losses in urine, sweat, and transepidermal routes. ${ }^{2} \mathrm{H}$, in fact, is lost almost entirely through body water losses like urination, but

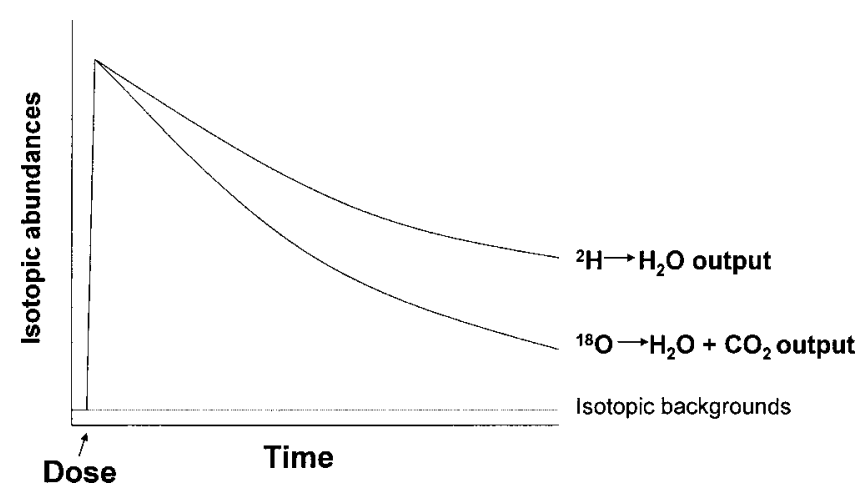

FIGURE 1. Isotope kinetics during the DLW method. Enrichment of the isotopes in doubly labeled water-oxygen $18\left({ }^{18} \mathrm{O}\right)$ and hydrogen $2\left({ }^{2} \mathrm{H}\right)$ following the dose and the elimination of both isotopes as they are cleared from the body and appear in the urine sample over time. 
${ }^{18} \mathrm{O}$ has a competing channel for loss: equilibration with $\mathrm{CO}_{2}$ in the lungs. Therefore, ${ }^{18} \mathrm{O}$ disappears more rapidly from the body than ${ }^{2} \mathrm{H}$. The difference in the rate constants for the disappearance of the two isotopes is proportional to the amount of $\mathrm{CO}_{2}$ produced and, therefore, indirectly to energy expenditure. There are several methods (Schoeller et al., 1986; Dallal \& Roberts, 1991; Matthews \& Gilker, 1995) for calculating energy expenditure from DLW data, but they all generate average daily TEE for the duration of the 2 week experiment. $\mathrm{H}_{2}{ }^{18} \mathrm{O}$ is very expensive and the analysis using the IRMS requires technical expertise. Additionally the DLW method is also limited by precision of only $4-7 \%$ for TEE and a limited time window of $0.5-$ 3 biological half-lives of the tracer (4-21 days in adults), but these are the only major limitations of the method.

DLW measurements of TEE have been used for revising the most recent recommendation of dietary energy needs for the US and Canadian Dietary Reference Intakes (DRI) (Institute of Medicine, 2002). The DRI equations below for calculating dietary energy requirements are based on TEE values obtained using the DLW method. In addition, TEE values for men and women with similar BMI but increasing heights are also shown in Table 3.

Several studies using DLW to measure energy expenditure in the obese have shown that TEE in overweight and obese individuals is not lower than that of normal weight individuals, and indeed in groups of subjects TEE increases with increasing body mass (Black et al., 1996; Prentice et al., 1996; Das et al., 2003). In sedentary populations, of both the non-obese and the obese, Table 4 (Prentice et al., 1996) shows that TEE increases significantly with increases in BMI.

In addition, TEE measurements by DLW have confirmed in all age groups and in all racial/ethnic groups, that regular vigorous exercise is an effective method of increasing TEE, reducing weight, and in reducing percent body fat. Table 5 (Prentice et al., 1996) shows how TEE is related to exercise.

Another recent study concluded that in obese adolescents physical activity is reduced but not energy expenditure (Ekelund et al., 2002), and likewise fat intake is related to obesity in childhood (McGloin et al., 2002). The results of these general trends toward increases in consumption of calories and fat are observable in population studies, which show striking increases in obesity in all age groups and racial/ethnic groups (Munsch, 2002). Results in our own laboratory confirm that extremely obese individuals have high rates of TEE and, therefore, must consume high levels of dietary energy to maintain their excess weight (Das et al., 2003). It is important to note that conclusions of increased EI with increasing body weight could only be obtained with DLW measurements, because of the widespread underreporting of EI among obese individuals (Schoeller, 1990).

Protein, lipid, and carbohydrate metabolism in obesity have been extensively studied by mass spectrometry. This review will explore each of these subjects in detail.

\section{PROTEIN METABOLISM}

\section{A. Amino Acid Flux and Whole Body Protein Turnover}

The application of mass spectrometry to the study of protein metabolism began with the classic work of Rudolph Schoen-
TABLE 3. Predictive equations for TEE as a function of age, physical activity, weight and height

(a) Equations to predict total energy expenditure (TEE) $\mathrm{kcal} / \mathrm{d}$ in females 19 years and older

TEE $=354.1-6.91 \times$ Age $[\mathrm{y}]+\mathrm{PA} \times(9.36 \times$ Weight $[\mathrm{kg}]+726 \times$ Height $[\mathrm{m}])$

Where PA is the physical activity coefficient:

$\mathrm{PA}=1.00$ if PAL is estimated to be $\geq 1.0<1.4$ (Sedentary)

$\mathrm{PA}=1.12$ if PAL is estimated to be $\geq 1.4<1.6$ (Low Active)

$\mathrm{PA}=1.27$ if PAL is estimated to be $\geq 1.6<1.9$ (Active)

$\mathrm{PA}=1.45$ if PAL is estimated to be $\geq 1.9<2.5$ (Very Active)

(b) Total energy expenditure (TEE; kcal/d) with increasing height (m)

$\begin{array}{lcc}\text { BMI } & \text { Height } & \text { TEE } \\ 20.00 & 1.55 & 1910 \\ 20.00 & 1.65 & 2061 \\ 20.00 & 1.75 & 2216 \\ 25.00 & 1.55 & 2036 \\ 25.00 & 1.65 & 2204 \\ 25.00 & 1.75 & 2377 \\ 30.00 & 1.55 & 2162 \\ 30.00 & 1.65 & 2347 \\ 30.00 & 1.75 & 2538 \\ 35.00 & 1.55 & 2288 \\ 35.00 & 1.65 & 2489 \\ 35.00 & 1.75 & 2699\end{array}$

(c) Equations to predict total energy expenditure (TEE; kcal/d) in males 19 years and older

$\mathrm{TEE}=661.8-9.53 \times$ Age $[\mathrm{y}]+\mathrm{PA} \times(15.91 \times$ Weight $[\mathrm{kg}]+$ $539.6 \times$ Height $[\mathrm{m}])$

Where PA is the physical activity coefficient:

$\mathrm{PA}=1.00$ if PAL is estimated to be $\geq 1.0<1.4$ (Sedentary)

$\mathrm{PA}=1.11$ if PAL is estimated to be $\geq 1.4<1.6$ (Low Active)

$\mathrm{PA}=1.25$ if PAL is estimated to be $\geq 1.6<1.9$ (Active)

$\mathrm{PA}=1.48$ if PAL is estimated to be $\geq 1.9<2.5$ (Very Active)

(d) Total energy expenditure (TEE; $\mathrm{kcal} / \mathrm{d}$ ) with increasing heights

BMI

20.00

20.00

Height

TEE

20.00

25.00

1.55

2152

$1.65-2328$

$1.75 \quad 2511$

$1.55 \quad 2364$

$25.00-1.65 \quad 2568$

$\begin{array}{lll}25.00 & 1.75 & 2782\end{array}$

$\begin{array}{lll}30.00 & 1.55 & 2576\end{array}$

$\begin{array}{lll}30.00 & 1.65 & 2809\end{array}$

$\begin{array}{lll}30.00 & 1.75 & 3053\end{array}$

$\begin{array}{lll}35.00 & 1.55 & 2788\end{array}$

$\begin{array}{lll}35.00 & 1.65 & 3050\end{array}$

\begin{tabular}{lll}
35.00 & 1.75 & 3324 \\
\hline
\end{tabular}

heimer with ${ }^{2} \mathrm{H}$ and ${ }^{15} \mathrm{~N}$, which established the dynamic nature of protein turnover (Young \& Ajami, 1999). The effects of lowcalorie and low-protein diets on amino acid and protein metabolism have been an important research focus since weight reduction is always the goal of therapy. Plasma amino acid levels, especially of the branched-chain amino acids, which are 
TABLE 4. The relationship between TEE and BMI

\begin{tabular}{lrr}
\hline & BMI & TEE $(\mathrm{MJ} / \mathrm{d})$ \\
\hline Women & $21.3 \pm 1.7$ & $9.51 \pm 1.57$ \\
& $27.7 \pm 1.5$ & $10.21 \pm 1.61$ \\
& $32.1 \pm 1.3$ & $11.36 \pm 1.72$ \\
& $43.6 \pm 6.4$ & $13.51 \pm 1.81$ \\
Men & $22.0 \pm 1.6$ & $12.89 \pm 2.59$ \\
& $26.6 \pm 1.3$ & $14.26 \pm 2.76$ \\
& $31.5 \pm 2.0$ & $16.42 \pm 3.93$ \\
& $44.4 \pm 8.4$ & $17.54 \pm 2.67$ \\
\hline
\end{tabular}

preferentially metabolized in the body's large muscle mass, are elevated in obesity (Caballero, Finer, \& Wurtman, 1988). Hoffer et al. (1988) compared ${ }^{2} \mathrm{H}$-alanine with ${ }^{15} \mathrm{~N}$-alanine given simultaneously, to measure alanine flux in the fed state in 16 obese women (130-199\% of ideal body weight) before and during a hypocaloric diet. With either isotope, the alanine flux decreased by $43 \%$ on the hypocaloric diet, but there was a $2-3$ times higher estimate of the alanine flux when the ${ }^{2} \mathrm{H}$ label was employed. The results with either isotope were highly correlated with one another and it was suggested that metabolic deuterium-proton exchange was probably responsible for the discrepancy, since mono and di-deutero alanine appeared in the plasma.

Because prolonged negative nitrogen balance is undesirable, the amount and quality of dietary protein in low-calorie diets is important. Garlick, Clugston, \& Waterlow, 1980 in an early study reported the effects of diet on protein turnover in two overweight (BMI 28) and three severely obese subjects (BMI 49). They reported that reduction of the daily caloric intake from 33 to $8 \mathrm{kcal} / \mathrm{kg} / \mathrm{d}$ with a reduction of protein from 70 to $50 \mathrm{~g} / \mathrm{d}$ did not alter protein turnover. Elimination of all dietary protein produced the expected decline in synthesis with a lesser decrease in catabolism. The study by Garlick, Clugston, \& Waterlow, 1980 also compared the use of a constant infusion of ${ }^{14} \mathrm{C}$-leucine with repeated oral doses, or a single oral dose, of ${ }^{15} \mathrm{~N}$-glycine and concluded that similar results were obtained with all three methods.

The effects of low-calorie diets for weight reduction on amino acid and protein metabolism have been the focus of several studies. Hoffer et al. (1984) compared the effects of isocaloric diets with 1.5 or $0.8 \mathrm{~g} \mathrm{~N} / \mathrm{kg}$ of ideal body weight on $\mathrm{N}$ balance and leucine or alanine flux in 17 obese women. $\mathrm{N}$ intake at $0.8 \mathrm{~g} / \mathrm{kg}$

TABLE 5. The relationship between TEE and exercise

TEE $(\mathrm{MJ} / \mathrm{d})$

\begin{tabular}{lr}
\hline Women & \\
Free living & $9.52 \pm 0.92$ \\
8 weeks training & $12.00 \pm 1.31$ \\
Men & $12.00 \pm 1.73$ \\
Free living & $14.23 \pm 1.46$ \\
8 weeks training & \\
\hline
\end{tabular}

resulted in a negative $\mathrm{N}$ balance. On either diet, basal rates (compared to fasting) of $\mathrm{N}$ turnover were maintained, while postabsorptive leucine and alanine flux decreased to a similar extent. With ${ }^{15} \mathrm{~N}$-glycine, Oi et al. (1987) found that on a lowcalorie diet of $1,100 \mathrm{kcal} / \mathrm{day}$ vs. $2,000 \mathrm{kcal} / \mathrm{d}$, reducing protein from 70 to $50 \mathrm{~g}$, protein synthesis rates were not maintained.

Gougeon et al. (1992) investigated the effect of an allprotein diet in seven premenopausal females (BMI 34.4). The subjects were given $1.7 \mathrm{MJ} / \mathrm{d}$ (407 kcal) of hydrolyzed gelatin supplemented with tryptophan and methionine for 6 weeks and were studied with oral ${ }^{15} \mathrm{~N}$-glycine, measuring urea enrichment. At week 6, the BMI had declined to 30.2. Whole body $\mathrm{N}$ flux did not change from the baseline to weeks 4 and 6 , but protein synthesis and catabolism declined, with a greater decline in synthesis resulting in a decline in net synthesis (synthesis minus catabolism) from +2.2 to $-0.9 \mathrm{~g} \mathrm{~N} / \mathrm{d}$ by the sixth week. Although $\mathrm{N}$ balance was present at the fourth week, it became negative at 5 weeks. Thus, this artificial low-calorie all-protein diet could not sustain $\mathrm{N}$ equilibrium if used for a prolonged period. A later study from the same laboratory (Gougeon, Pencharz, \& Marliss, 1995) compared the supplemented gelatin diet with a casein-soy lowcalorie diet in six subjects-one male and five female (BMI 33). At week 6, protein synthesis had decreased with either diet, but the catabolic rate declined only on the casein-soy diet, resulting in $\mathrm{N}$ equilibrium for the soy-protein diet at that time, suggesting it might be superior for prolonged use.

Marchini et al. (2001) supplemented a low-energy diet $(4.2 \mathrm{MJ} / \mathrm{d}$ and $0.6 \mathrm{~g}$ protein/d) in obese women (BMI 33) with leucine, arginine, or glycine and measured protein turnover with a single dose of ${ }^{15} \mathrm{~N}$-glycine. Supplementation with any of these amino acids at the level of $0.2 \mathrm{~g}$ of protein equivalent did not alter protein synthesis or breakdown nor did it change the plasma amino acid composition, indicating that $0.6 \mathrm{~g} / \mathrm{kg} / \mathrm{day}$ of dietary protein maintained protein turnover on the low-energy diet.

Hoffer \& Forse (1990) found that after a 3-week fasting period in 10 moderately obese women, followed by 1 week of refeeding, there was improved efficiency of protein retention during the fasting period, which was related to a decreased protein turnover. After protein refeeding, $\mathrm{N}$ balance became positive while ${ }^{13} \mathrm{C}$-leucine flux was unchanged from the fasting value.

Bruce et al. (1990) tested the hypothesis of greater metabolic efficiency in six obese subjects (BMI 45), compared to six lean controls, employing studies of nutrient oxidation patterns as well as protein metabolism. ${ }^{13} \mathrm{C}$-leucine was used to measure protein oxidation and synthesis after feeding. On a fat-free mass basis, in the obese subjects the increase in protein oxidation was less compared to the controls. The rates of protein synthesis were greater in both fasting and feeding in the obese subjects. Measurements of TEE with $\mathrm{D}_{2} \mathrm{O}$ indicated no differences on a fat-free body mass basis during fasting or feeding. It was concluded that the hypothesis of greater metabolic efficiency in obesity was not supported by their data.

Obesity and insulin resistance go hand in hand. Using the euglycemic hyperinsulinemic clamp method to assess insulin resistance in obese (premenopausal but not diabetic) women, Caballero \& Wurtman (1991) found that compared to lean controls, the insulin-induced decrease in plasma levels of branchedchain amino acids was less in obesity. However, baseline leucine flux, using ${ }^{13} \mathrm{C}$-leucine, as well as its decline in response to 
insulin, was similar. A highly significant correlation $\left(\mathrm{r}^{2}=0.93\right)$ was found between lean body mass and the plasma level of the branched chain amino acids. They concluded that the plasma amino acid levels in obesity were not necessarily associated with impaired insulin-mediated amino acid flux in spite of the lesser responsiveness during the insulin clamp. The use of ${ }^{13} \mathrm{C}$-leucine in kinetic studies, rather than relying on measuring the ${ }^{15} \mathrm{~N}$ enrichment of urea, may be preferable, since Ang, Halliday, \& Powell-Tuck, 1995 found that in non-obese subjects during the euglycemic hyperinsulinemic clamp, insulin's effect on $\mathrm{NH}_{3}$ excretion complicated the interpretation of the results.

\section{B. Childhood Obesity}

Obesity in children tends to be perpetuated into adult life (Serdula et al., 1993). It is a particularly difficult disorder to treat because of the energy and protein requirements for growth. Schutz et al. (1999) measured whole body protein turnover and resting energy expenditure in nine obese children (average age 8.6), using the methodology of ${ }^{15} \mathrm{~N}$ enrichment of urinary ammonia after ${ }^{15} \mathrm{~N}$ glycine administration. Absolute rates of protein synthesis were $52 \%$ greater than in eight lean controls, and of protein catabolism were $67 \%$ greater. However, these differences were not present when the results were corrected for fat-free body mass. Protein synthesis was highly correlated with fat-free body mass and with resting energy expenditure. One weakness of this study is the reliance on urinary ammonia nitrogen enrichment, which could be affected by differences in insulin action, as noted above. However, although obese, it is not known whether these children had any alteration in insulin sensitivity, though this seems unlikely with normal growth in childhood.

Ebbeling \& Rodriguez (1998) studied 16 children, aged 8 10 , using ${ }^{15} \mathrm{~N}$-glycine to measure nitrogen flux, protein synthesis, and protein catabolism. Over a 6-week period, caloric restriction resulted in an average weight loss of $2.2 \mathrm{~kg}$ of which $1.9 \mathrm{~kg}$ was FM. Caloric restriction caused a decrease of approximately $35 \%$ in net protein turnover because of a decrease in protein synthesis; that decrease sounds a cautionary note from the therapeutic standpoint. In six of these children, when an additional 6 weeks of exercise was added to the initial 6-week diet period, the total weight loss averaged $4.2 \mathrm{~kg}$ and there was an increase in protein synthesis. However, there was a concurrent increase in protein catabolism and an increase in nitrogen flux. It would appear that exercise plus caloric reduction is superior to changes in diet alone.

In 16 adolescents, Pencharz et al. (1988) reported that $2.5 \mathrm{~g} /$ $\mathrm{d} / \mathrm{kg}$ ideal body weight of high quality (animal) protein increased $\mathrm{N}$ flux from a single dose of ${ }^{15} \mathrm{~N}$-glycine to urea, but not ammonia, by day 4 . By day 7 up to day $18, \mathrm{~N}$ flux returned to normal.

\section{Plasma Apolipoprotein Metabolism}

\section{Introduction}

In the Framingham Offspring Study (Lamon-Fava, Wilson, \& Schaefer, 1996) the age-adjusted BMI was positively correlated with systolic blood pressure, fasting glucose, the cholesterol content of very low density lipoprotein (VLDL) and low density lipoprotein (LDL); and inversely correlated with high density lipoprotein (HDL) cholesterol levels. Moreover, high triglycerides and small LDL particles were also positively associated with higher BMI values. The high plasma levels of apoB-100 and the low levels of apoA-I, the main apolipoproteins of LDL and HDL, were also highly correlated with the BMI. All of these lipoprotein changes related to obesity are well known risk factors for atherosclerotic coronary heart disease. For this reason, studies of apolipoprotein metabolism in obesity are very important.

\section{Stable Isotope Infusions: Primed Constant Infusion versus Bolus}

To determine the fractional catabolic rate (FCR) of any plasma protein, a labeled amino acid precursor is infused intravenously and the intracellular isotopic enrichment of the amino acid determined. Leucine, valine, and lysine have been found to be equally effective as labeled precursors (Lichtenstein et al., 1990; Marsh et al., 2002). For apolipoproteins, when the labeled amino acid is given as a primed constant infusion (a bolus of the isotope followed by a constant infusion during the course of the sampling period), the hepatic intracellular precursor enrichment is closely approximated by the enrichment of VLDL apoB-100 at plateau (Cryer et al., 1986; Cohn et al., 1990; Marsh \& Diffenderfer, 1991). The steady state enrichment of the plasma amino acid during the infusion may also be used; however, since its enrichment is usually greater than intracellular enrichment, a correction factor based on the apoB-100 plateau must be used. Welty et al. (1999) have shown that the enrichment of VLDL apoB-100 at plateau is approximately $75 \%$ of that of plasma. Of note, VLDL apoB-100 does not reach a plateau in subjects with high VLDL (triglyceride) levels; therefore, one may assume that the relationship between the VLDL apoB-100 plateau and plasma amino acid enrichment is the same as in normal subjects assuming no abnormalities of amino acid metabolism.

When the labeled amino acid isotope is given intravenously as a bolus, one sees a rise in the enrichment curve and then a dieaway of the isotope curve. The shape of the amino acid enrichment curve including the die-away is used in the mathematical modeling of the FCR, and the plasma amino acid enrichment is usually used as the estimate of the intracellular amino acid precursor enrichment. A metabolite of the amino acid (such as hippurate in the case of glycine or alpha-keto isocaproic acid in the case of leucine) may also be employed. Since it may be metabolized in a different compartment within the cell, it may have a different isotopic enrichment and, therefore, does not necessarily solve the problem of estimating the intracellular isotopic precursor enrichment (Marsh \& Diffenderfer, 1991). Administering the labeled amino acid orally rather than intravenously has provided disappointing results probably because of variability in intestinal absorption (Sumner et al., 1999).

\section{Stable Isotope Infusion Data Analysis and Modeling}

The kinetic parameters (FSR/FCR and PR) can be determined with multicompartmental analysis (Duvillard, Verges, \& Gambert, 1998) of the isotopic enrichment and apoB pool sizes using SAAM II (1994) (SAAM Institute, Seattle, WA, 1994). 
This computer-based program determines the best fit to the actual data points using a multicompartmental model. It is recommended that several models be tried to determine which fits the data points best. Many multicompartmental models of apoB metabolism, ranging from simple to very complex, have been described. Some general points about modeling are important to consider in developing a model for one's data.

Two important tenets of modeling theory are that one must use the simplest solution to the differential equations and that they must have a unique solution. Thus, one should not artificially fix any parameter in the model since this would alter a potential fit and thus affect the solution. In addition, it would limit the ability to arrive at a unique solution. Complex models often have too many variables to allow a unique solution and, therefore, require that some parameters be fixed (constrained). As a result, the physiological relevance is often not clear. If one fixed the same parameters with each solution, the results would most likely be more consistent; however, this is often not done.

With respect to apoB-100 kinetics in the human, representative models for apoB-100 kinetics either have all apoB-100 secreted from the liver into VLDL and then to IDL and LDL or allow for direct input from the liver into all three compartments. Ideally, one should use both types of models and use the one giving the best fit to the data. The first model should have all apoB-100 going directly into VLDL and then to IDL and LDL via a delipidation cascade. The alternative model allows apoB-100 to be directly secreted into VLDL, IDL, and LDL in addition to delipidation of VLDL to IDL and LDL. The addition of direct inputs into IDL and LDL in the direct input model introduces more parameters, and thus, the model may be undefined. Rarely has an investigator presented both models to prove the superiority of the one chosen. For further discussion of apoB-100 models, see the articles by Foster et al. (1993) and Cobelli et al. (1987). Welty et al. (1999) present models for apoB-100 and apoB-48. apoA-I, A-II, and apoE models are currently under development by Welty and will be similar to the apoB-48 model (Welty et al., 1999).

\section{Tracer Kinetics Results for Apolipoproteins}

The apoB-100 of VLDL is the main precursor of the apoB-100 of LDL, and its tracer kinetics track the fate of the particle, which contains most of the circulating triglyceride in the fasting state. In six obese subjects (BMI 37.6) compared to matched controls (BMI 23), the VLDL pool size and production (synthesis) rate of apoB-100 were increased 6- and 4-fold, respectively (Cummings et al., 1995). There was a concomitant 50\% decrease in VLDL apoB-100 clearance, though at a $P$-value of 0.06 in this study. Because insulin levels were correlated with the VLDL-apoB-100 production rate (PR), it was suggested that insulin resistance might be responsible for the increased PR in obesity.

In a similar study of 16 men with visceral obesity, Riches et al. (1998) reported a secretion rate for VLDL-apoB-100 of $24.2 \mathrm{mg} / \mathrm{kg}$ of fat-free mass/day compared to $14.8 \mathrm{mg} / \mathrm{kg} \mathrm{FFM} / \mathrm{d}$ in 16 matched controls $(P=0.017)$. They also found a $41 \%$ decrease in the FCR, from 9.7 to 5.7 pools $/ \mathrm{d}(P=0.053)$. In five insulin-resistant women with abdominal obesity, Pont et al. (2002a) found an $84 \%$ increase in the PR of apoB-100 in VLDL, a $54 \%$ increase in IDL PR, and a $63 \%$ increase in LDL. No changes in FCR were noted.
In five insulin-resistant and obese young African-American males, compared to five controls, Sumner et al. (1999) reported a decreased FCR of apoB-100 in large and small VLDL and IDL, which accounted for the higher TG levels.

In the study by Chan et al. (2002b), the plasma apoC-III concentration was significantly positively correlated with both the secretion rate of VLDL-apoB-100 and negatively with its conversion to $\operatorname{LDL}(r=0.51$ and 0.41 , respectively). The significance of these correlations lies in the fact that apoC-III, or a high ratio of apoC-III to that of apoC-II (the lipoprotein lipase activator), inhibits the action of lipoprotein lipase in the lipolysis of VLDL (Graziani et al., 1994). Furthermore, the apoC-III gene is under the control of insulin (Li et al., 1995), suggesting a link between obesity and insulin resistance. The findings of the study by Chan et al. (2002a) indicate that visceral obesity, at least in men, causes increased production of VLDL and decreased catabolism of the apoB-100 lipoproteins, resulting in the elevation of plasma levels and hence an increased cardiovascular risk.

Further evidence that visceral and not posterior or anterior subcutaneous abdominal adipose tissue is the best predictor of VLDL-apoB-100 secretion has been found in a group of 51 overweight or obese men by Chan, Watts, \& Barrett, 2003. In a related study from the same laboratory, it was reported that the intraperitoneal adipose mass was the best predictor of VLDL apoB-100 secretion, whereas the total adipose tissue mass was the best predictor of the FCR (Watts et al., 2003). Moreover, the intraperitoneal adipose mass was associated with VLDL apoB100 secretion rates even after adjusting for age, dietary intake, or insulin resistance. Insulin resistance per se (as determined by the HOMA score) appeared to affect the FCR since none of the fat compartments were significantly associated with the FCR after adjusting for the HOMA score.

Chan et al. (2002c) also examined the effect of atorvastatin, an HMGCoA Reductase inhibitor, on apoB-100 kinetics in 25 men with visceral obesity (defined as a BMI $>29$ and a waist circumference $>100 \mathrm{~cm}$ ). The drug produced a decrease in all of the apoB-containing plasma lipoproteins as well as a decrease in lathosterol, a marker of cholesterol synthesis. These declines were because of increases in the FCR's for VLDL, IDL, and LDL apoB-100, with no changes in the PR, therefore, up-regulation of the LDL receptors in the liver resulting from a primary decrease in cholesterol biosynthesis is probably responsible for the effects of the statins in lowering apoB-100 levels in obesity, with its concomitant state of insulin resistance. Previous studies of statin effects in non-obese individuals have not given consistent results with regard to whether or not a decreased PR or an increased FCR was the main effect (Marsh et al., 2002).

During VLDL catabolism, remnants (intermediate density lipoproteins) are produced which are one of the markers of atherosclerosis risk (Seman, McNamara, \& Schaefer, 1999). The plasma levels of VLDL remnants were increased in 48 men with visceral obesity who were also insulin resistant (Chan et al., 2002a). In the companion study (Chan et al., 2002b) compared to 10 lean controls, these subjects had elevated plasma levels of triglycerides, LDL-cholesterol, apoB-100 in VLDL, IDL, and LDL, and apolipoprotein C-III. In addition, insulin and lathosterol levels (a marker of cholesterol synthesis) were increased. When apoB-100 kinetics were measured using a bolus dose of deuteroleucine, the VLDL-apoB-100 secretion (production) rate 
was increased from 9.7 to $14.7 \mathrm{mg} / \mathrm{kg} / \mathrm{d}$, while the FCR of IDLapoB-100 was decreased from 6.1 to 4.3 pools/d. The LDL apoB$100 \mathrm{FCR}$ also decreased, from 0.43 to 0.27 pools/d. In addition, the conversion of VLDL-apoB-100 to IDL declined from 58 to $38 \%$, and its direct conversion to LDL decreased from 50 to $28 \%$. These results with stable isotopes are in general agreement with those obtained in earlier work using ${ }^{125}$ I-labeled autologous VLDL and LDL and ${ }^{3} \mathrm{H}$-glycerol (Egusa et al., 1985).

Although postprandial elevation of triglycerides in chylomicrons is also a feature of obesity, the metabolism of the structural apolipoprotein apoB-48 associated with the particle has not yet been studied with stable isotopes. Couillard et al. (2002) have reported increased postprandial levels of apoB-48 in abdominally obese men. As discussed in the next section, Watts et al. (2001) have developed a stable isotope breath test to study chylomicron remnant metabolism in obesity.

Because high TG levels are associated with low HDL, and this situation is characteristic of obesity with insulin resistance, Pont et al. (2002b) studied apoA-I kinetics in five obese and insulin resistant women, compared to five controls. An increased FCR was found, which correlated with TG levels in the fed state. It was, therefore, suggested that an increased TG content of the HDL, which is known to be associated with an increased FCR (Marsh, Welty, \& Schaefer, 2000) could explain the low HDL in obesity.

Apolipoprotein A-IV, made by the intestine, appears to have a role in appetite control in the CNS since it inhibits food intake in rats (Tso et al., 2001). Doi et al. (2001) have suggested that chronic ingestion of a high fat diet blunts the intestinal apoA-IV response to lipid feeding and, therefore, may be involved in the development of obesity. The metabolism of apoA-IV in nonobese humans has been studied with stable isotopes. Sun et al. (2001) showed that the residence time (RT) of apoA-IV within the VLDL plus chylomicron fraction (the TRL fraction) was much longer (RT of 2 days) than that of chylomicron-associated apoB-48. These data suggest an exchange of lipid-poor apoA-IV with HDL and indicate that its synthesis rate primarily determines the level in the TRL. Access to the CNS may be enhanced by the ability of apoA-IV to exist in a lipid-poor state.

\section{LIPID METABOLISM}

The mammalian species has evolved to utilize fatty acids as its major metabolic fuel because fat has twice the caloric value of carbohydrate, does not require hydration in its storage form, and weighs less. In addition storage of energy in white adipose tissue in many different depots, brown adipose tissue influences heat production (Zhang et al., 2001) and the secretion of TG-rich lipoproteins as found in animal models (Siri et al., 2001). Moreover, adipocytes are part of the endocrine system since they secrete hormones such as leptin, resistin, and adiponectin (Ahima \& Flier, 2000; Shuldiner, Yang, \& Gong, 2001), which are involved in metabolic regulatory processes (Jequier, 2002). In vitro studies have been facilitated by the fact that adipocytes can be readily obtained and cultured from humans as well as from animals. To store excess energy in adipocytes, triglyceride synthesis must exceed its breakdown to fatty acids. Hence, studies of TG turnover in the whole animal can shed considerable light on overall lipid metabolism in obesity. A complete discussion of adipocyte function is beyond the scope of this review. Several reviews on the techniques of the use of stable isotopes in studies of lipid metabolism have been published (Lee et al., 1994; Hellerstein, 1996; Beylot et al., 1997; Brenna, 1997; Koletzko et al., 1998; Coggan, 1999; Landau, 1999; Emken, 2001).

\section{A. Lipogenesis and Fatty Acid Metabolism in Humans}

Is obesity associated with an increase in de novo fatty acid synthesis and subsequent storage as TG? The incorporation of $\mathrm{D}_{2} \mathrm{O}$ into TG-fatty acids, the injection of labeled fatty acids, the incorporation of labeled glycerol into blood or tissue TG, or the mass isotopomer analysis of fatty acids after injection of the label, have all been employed in studies of lipogenesis in animals and humans.

Guo et al. (2000) studied de novo lipogenesis in six lean and six obese (BMI 36) premenopausal women using $\mathrm{D}_{2} \mathrm{O}$ and IRMS. The fractional synthesis rate (FSR) of TG-fatty acids in fat biopsy samples from different sites averaged 0.014/day in each group, although in four obese and one lean subjects, the FSR was too low to measure. The total synthesis rate averaged $2.0 \pm 0.7$ and $5.6 \pm 3.2 \mathrm{~g} / \mathrm{d}$ in the lean and obese women, respectively; approximately $0.02 \%$ of whole body fat. In agreement with studies in normal subjects, the authors concluded that de novo lipogenesis by adipose tissue or liver contributes only a small fraction to whole body lipogenesis. Consequently, an overall increase in this process cannot account for obesity.

However, increased hepatic lipogenesis with a consequent rise in plasma TG does occur in obese subjects. Marques-Lopes et al. (2001) infused ${ }^{13} \mathrm{C}$-acetate before or after a high carbohydrate-low fat meal in six lean and seven overweight men. By mass isotopomer distribution analysis, it was found that there was lower lipid oxidation and that de novo lipogenesis was increased both before and after the meal in the overweight men. This was accompanied by increased insulin, fatty acid, and TG levels, and by greater TEE, without any change in carbohydrate oxidation.

A stable isotope study in non-obese subjects showed that a high carbohydrate diet increased hepatic lipogenesis, but it did not modify lipogenesis in adipose tissue of obese individuals (Delzenne et al., 2001).

Considering the fact that fat constitutes the major metabolic fuel, could obesity be associated with a decreased rate of adipose TG lipolysis? Klein et al. (1988) determined lipolytic rates after infusion of ${ }^{13} \mathrm{C}$-palmitate and ${ }^{2} \mathrm{H}$-glycerol in a $12-15 \mathrm{hr}$ fast and a $60-87 \mathrm{hr}$ fast in normal weight and obese young adults. Lipolytic rates per unit of FM were inversely related to the FM, but were similar when expressed as a function of lean body mass. Thus, in obesity, lipolysis rates appear to adjust to the metabolic fuel requirements of the lean body mass but a primary defect in lipolysis under fasting conditions does not explain obesity.

What about the response to stress accompanied by a rise in epinephrine levels? Horowitz \& Klein (2000) studied 10 women with upper body obesity (BMI 38) compared to 8 lean controls (BMI 21). Keeping glucagon and insulin constant, epinephrine 
was infused and whole body free fatty acid (FFA) and glycerol turnover were measured using ${ }^{13} \mathrm{C}$-palmitate and ${ }^{2} \mathrm{H}$-glycerol. Rates of appearance of FFA or glycerol in plasma were increased from 323 (FFA) and 167 (glycerol) $\mu$ moles/min in the lean subjects to 449 and $220 \mu$ moles/min in the obese subjects. Epinephrine infusion significantly increased these basal rates (by 71 and $122 \%$, respectively) only in the lean subjects. Only the abdominal, not the femoral, subcutaneous adipose tissue showed this decreased response to epinephrine. A secondary rise in insulin, which inhibits hormone-sensitive tissue lipase, probably prevents a sustained rise in lipolysis. The study by Horowitz \& Klein (2000), therefore, supports the concept that visceral obesity, which is mainly associated with an increased risk of atherosclerosis, may involve regulation of lipolysis in abdominal adipose tissue (Wajchenberg, 2001).

Adjustment to obesity at the level of fatty acid oxidation was demonstrated in prepubertal children with a wide range of body fat, from 9 to $64 \%$ of body weight (Maffeis et al., 1999). ${ }^{13} \mathrm{C}$ labeled fatty acids were added to a mixed meal and indirect calorimetry was employed to differentiate between endogenous and exogenous fat oxidation over a $9 \mathrm{hr}$ postprandial period. During this period, fat oxidation equaled the amount ingested. Exogenous fat oxidation accounted for $11 \%$ of the total fat oxidation and it increased as a percentage of the total as the body FM increased $(r=0.56)$. Without this adjustment, body FM would have continued to increase.

In extreme obesity, gastric bypass surgery has been employed to induce weight loss. Weight regain after this procedure usually occurs. In an effort to delineate changes in dietary fat metabolism, Faraj et al. (2001) studied eight postobese women 2-3 years after surgery and eight matched controls. After a high fat meal containing ${ }^{13} \mathrm{C}$-oleate, the main differences in the post-obese subjects were found to be in the isotopic enrichment of plasma non-esterified fatty acids FFA. The controls showed a steady rise in enrichment over an $8 \mathrm{hr}$ period while the postobese subjects showed very little enrichment. Comparing the area under the enrichment curve, the postobese subjects had a highly significant $72 \%$ decrease in enrichment. They also had lower plasma levels of postprandial insulin and acylation-stimulating protein. Their fasting leptin levels were also decreased. The authors suggest that increased efficiency of dietary fat storage could contribute to regaining weight after by-pass surgery.

An interesting approach to the question of hormonal regulation of FM was reported by Lucidi et al. (2002) who gave low doses of human growth hormone $(\mathrm{GH})$ to six obese men (BMI 33) with visceral obesity and used labeled glycerol, glucose, or leucine to measure metabolic rates. Although $\mathrm{GH}$ stimulated insulin secretion, its overall lipolytic effect prevailed and a $25 \%$ increase in lipolysis was observed without any significant change in glucose or protein turnover. Similar studies with glucagon have not been reported, but would be of interest.

\section{B. Animal Studies}

In the obese Zucker rat, the possibility that changes in substrate cycling (from TG to FFA and vice versa), which would waste energy, could contribute to the maintenance of the obesity was investigated (Chatzidakis, Lazarus, \& Stein, 1994). Using ${ }^{13} \mathrm{C}$ palmitate, ${ }^{2} \mathrm{H}$-labeled glycerol, and ${ }^{15} \mathrm{~N}$ or ${ }^{2} \mathrm{H}$ - glucose, no differences in substrate cycling between obese and lean controls were found, irrespective of the level of EI.

The recent observations of Cohen et al. (2002) that in obese (ob/ob) mice with a mutation in the leptin gene have very low levels of stearoyl-CoA desaturase-1 (SCD-1) has opened a new field of inquiry in obesity, insulin resistance, and diabetes. The livers of ob/ob mice were fatty and VLDL secretion was low; these effects were reversed by leptin administration. The effects of leptin requires receptors in the central nervous system, since mice in which removal of the leptin receptor gene in neurons but not in the liver resulted in the obese phenotype (Cohen et al., 2001). Mice in which the gene for SCD-1 is lacking have impaired synthesis of hepatic TG and CE with low levels of VLDL-TG (Miyazaki et al., 2000). Interestingly, feeding dietary triolein or tripalmitolein did not restore hepatic TG or CE levels. SCD-1 null mice are protected from obesity, have increased energy expenditure and increased ketone body formation (Ntambi et al., 2002). The mechanism by which the desaturase deficiency results in these changes is not yet clear. Stable isotopes have been used to show that in humans, the overall conversion of dietary stearic acid to plasma oleic acid was approximately $14 \%$ over a 6-day period, with the labeled oleate appearing mainly in chylomicrons and VLDL (Rhee et al., 1997), therefore, SCD-1 is active and important in humans as well as in mice.

\section{Plasma Lipoprotein-Lipid Metabolism}

Although studies of apolipoproteins have been carried out, particularly of apoB, which carry the plasma lipids directly related to VLDL and chylomicron particle metabolism, it is really the lipid content of the particle, especially TG and CE, which is of greatest interest in obesity. Recently, a test that measures clearance from the plasma of lipid emulsions resembling chylomicron remnants and containing cholesterol- ${ }^{13} \mathrm{C}$-oleate has been developed (Watts et al., 2001). The isotopic enrichment of ${ }^{14} \mathrm{CO}_{2}$ appearing in the breath is then measured using IRMS. Using this test, 12 men with central obesity and 12 controls were studied. The controls were matched for age, plasma cholesterol, and plasma TG. The FCR of this labeled lipid emulsion was markedly less in the obese subjects- 0.061 vs. 0.20 pools $/ \mathrm{hr}$, and was inversely associated with the waist/hip ratio (the best predictor of the FCR), as well as with plasma TG and cholesterol levels. The authors suggest that post-absorptive chylomicron remnant catabolism in obesity is decreased in central obesity even in subjects without hyperlipidemia and appears to be related to the degree of central adiposity. When the HMGCoA Reductase inhibitor atorvastatin was given to 25 obese men with high TG, the levels of remnant-like cholesterol particles as well as other lipid parameters (LDL-C, TG, apoB) were decreased. The FCR of the labeled $\mathrm{CE}$ in the emulsion was correspondingly increased, and was inversely associated with the level of LDL-C $(\mathrm{r}=-0.58)$.

Mittendorfer, Patterson, \& Klein (2003a) studied VLDL-TG metabolism in abdominally obese men and women (10 subjects each, BMI of 35), they found that the basal PR (production rate) of VLDL-TG, as judged by ${ }^{2} \mathrm{H}$-glycerol kinetics, was twice as great in lean women than in lean men. In the obese men, VLDLTG secretion was $36 \%$ greater than in the obese women, but the obese women did not show an increase compared to the 
lean controls. With regard to TG clearance rates, the lean women cleared 1.5 times as fast as the lean men did, whereas the lean men and all of the obese subjects cleared TG at approximately equal rates. For all of the subjects, the plasma TG was directly correlated with the PR in men and inversely correlated with the clearance rate in women.

Mittendorfer, Patterson, \& Klein (2003b) also studied the effect of a $10 \%$ weight loss on VLDL-TG and apoB-100 kinetics in seven women with abdominal obesity (BMI 36) and in six lean women (BMI 21). They found that the VLDL-TG secretion rate was decreased by $40 \%$. There was no change in VLDL-apoB-100 secretion, which implies a relatively greater secretion of the smaller $\left(\mathrm{VLDL}_{2}\right)$ particles. In many earlier studies in perfused rat liver, fatty acid infusions increased the size of secreted VLDL to a greater extent than the number of apoB-100-containing particles (Salam, Wilcox, \& Heimberg, 1988). Most of the decline in TG production after weight loss was related to non-sytemic fatty acids derived from intraperitoneal and intrahepatic TG rather than from systemic fatty acids coming from subcutaneous fat (Mittendorfer, Patterson, \& Klein, 2003b). A proposed paradigm for the dyslipidemia of obesity is shown in Figure 2 below.

The paradigm points to visceral adipose tissue as the central organ responding to obesity-related insulin resistance by increasing the release of free fatty acids, probably because of decreased inhibition of adipocyte hormone-sensitive lipase. When carried to the liver via the portal vein, fatty acid binding to nuclear hormone receptors, such as PPAR's and LXR's, may exert regulatory control of hepatic lipogenesis and VLDL production (Edwards, Kast, \& Anisfeld, 2002). The liver then secretes more fatty acids in the form of VLDL-TG and VLDL-CE. Moreover, production of oleic acid via endogenous desaturation of stearic acid and its esterification to cholesterol, may be an important determinant of overall VLDL production (Cohen et al., 2002), which is increased in obesity. $\mathrm{CE}$ and apoC-III enrichment of VLDL will retard lipolysis and result in a decreased FCR, especially in obese women (Mittendorfer, Patterson, \& Klein, 2003a). The result will be high TG levels typical of obesity. In turn, the enrichment of HDL with TG via the action of CETP results in an increased FCR, accounting for the association of low HDL with high TG.

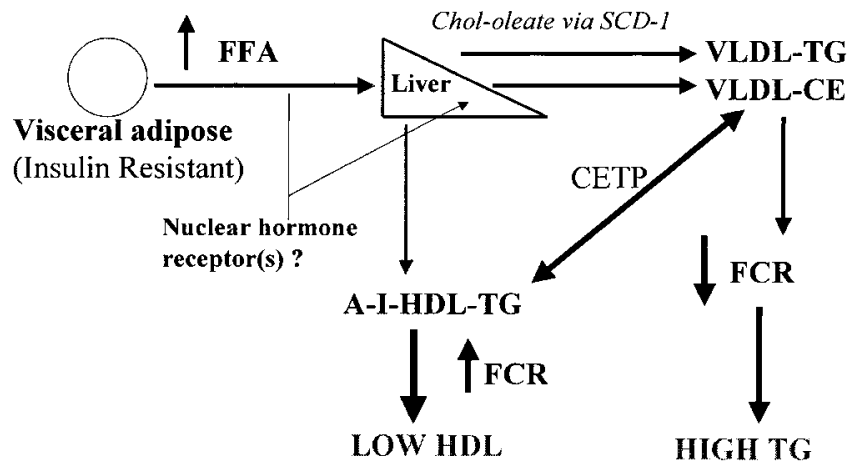

FIGURE 2. Paradigm for the dyslipidemia of obesity. A paradigm for the overall mechanism of the dyslipidemia associated with obesity, insulin resistance, and NIDDM. When NIDDM ensues, low Lplipase contributes to decreased clearance of VLDL.

\section{Whole Body Cholesterol Metabolism}

Studies of whole body cholesterol metabolism are pertinent, because of the association of obesity with lipoprotein metabolism involving elevated cholesterol levels, and the fact that adipose tissue contains a mobilizable source of plasma cholesterol. However, there have been few studies of overall cholesterol metabolism per se in obesity to date. Although $\mathrm{D}_{2} \mathrm{O}$ incorporation has been employed for some time to measure cholesterol biosynthesis, the mass isotopomer distribution method has been shown to give equivalent results (DiBuono et al., 2000). Though not yet applied to studies in obesity, a new dual-stable isotope method has been developed using labeled leucine and acetate. Use of this method shed light on reverse cholesterol transport and the lower levels of HDL-C in obesity (Ougerram et al., 2002).

Cholesterol synthesis has a diurnal rhythm, and this rhythm depends on the timing of food intake in relation to the sleep/wake cycle (Cella, Van Cauter, \& Schoeller, 1995). Whether or not this observation will prove pertinent to studies of obesity remains to be seen.

\section{CARBOHYDRATE METABOLISM}

In most diets, more calories are derived from carbohydrate than from protein or fat, though all of these components can contribute to TG synthesis. As individuals become obese, the risk of developing insulin resistance and subsequently diabetes (NIDDM) rises. In an early study, Ravussin et al. (1980) found that in five obese subjects (defined as $>149 \%$ of ideal weight) with normal glucose tolerance but increased insulin levels, an oral glucose load (with its natural abundance of ${ }^{13} \mathrm{C}$ ) resulted in isotopic enrichment of expired $\mathrm{CO}_{2}$. In combination with indirect calorimetry, estimates of carbohydrate utilization were made. The obese subjects had a significant increase in the carbohydrate balance (from 17 to $34 \mathrm{~g}$ ) because of a decrease in utilization. Since the non-protein RQ never rose above 1.0, net lipogenesis was assumed not to be responsible, suggesting a relatively greater fatty acid oxidation.

One of the questions needing to be answered is the extent to which endogenous glucose production, either from glycogenolysis or from gluconeogenesis, may be altered in obesity. Muller et al. (1997) studied six lean and five obese (BMI 38) non-diabetic subjects receiving $0.3 \mathrm{~g} /$ day of uniformly labeled ${ }^{13} \mathrm{C}$-glucose for 2 days to label glycogen. Then ${ }^{13} \mathrm{C}$-glycogen enrichment was calculated from the respiratory ${ }^{13} \mathrm{CO}_{2}$. Endogenous glucose production was measured after injection of ${ }^{2} \mathrm{H}$-glucose. No significant difference was found between the lean and obese subjects. The fractional rate of gluconeogenesis was obtained from the ${ }^{13} \mathrm{C}$-glucose $/{ }^{13} \mathrm{C}$-glycogen ratio and this fraction was $59 \%$ in the obese and 29\% in the lean subjects. Direct measurements of liver glycogen were made, and this value was increased in obesity by $67 \%$. The authors concluded that in obesity, the overall endogenous glucose production is not changed because glycogenolysis is decreased while gluconeogenesis is increased.

In agreement with these results on gluconeogensis, Stunff \& Bougneres (1996), used a double stable isotope infusion method, and they reported that in five obese children, there was a $50 \%$ increase in total body lactate turnover, with twice the rate of 
conversion to glucose, compared with five controls. The amount of lactate coming from plasma glucose was significantly correlated with lipid oxidation, which was increased from 23 to $58 \mathrm{mg} / \mathrm{min}$, in the obese children.

Glycogen synthesis in non-diabetic obese subjects with impaired glucose tolerance and in lean controls has also been studied by injecting ${ }^{13} \mathrm{C}$-galactose after ingestion of a glucose load (Paquot et al., 2000). By measuring urinary acetaminophen glucuronide enrichment, estimates of hepatic glycogen kinetics can be made. In their six obese subjects (three male, three female, BMI 32) and six controls, net hepatic glycogen synthesis accounted for $18.6 \pm 3.0 \%$ and $22.6 \pm 2.8 \%$ of the glucose load in the lean and obese subjects, respectively. Postprandial hepatic glycogen metabolism in obesity was, therefore, not impaired.

\section{SUMMARY}

Research efforts addressing the problem of obesity in humans have been greatly aided by the application of stable isotope techniques and mass spectrometry. Body composition and TEE can be measured by mass spectrometry using stable isotope labeled water, and the metabolism of protein, lipid and carbohydrate can be measured using appropriate labeled tracer molecules.

Increasing levels of obesity are characterized by dramatic increases in percent body fat and concomitant increases in TEE. High caloric intakes are required to attain and maintain obesity. Nevertheless, free-living persons often find reduced-calorie diets difficult to follow. Regular vigorous exercise is often a more effective approach to reducing obesity.

Avoidance of negative nitrogen balance with low-calorie diets is difficult. Studies to date suggest that at least $0.6 \mathrm{~g}$ of high quality protein per $\mathrm{kg}$ per day is needed. There has been no support for the hypothesis of greater metabolic efficiency as a determinant of obesity. There has also been little support for the idea that higher plasma levels of the branched chain amino acids in obesity could be because of obesity-related insulin resistance to amino acid flux rates. Therefore, one can hypothesize that decreased utilization by muscle, perhaps related to a more sedentary lifestyle, may be responsible. Increased exercise plus caloric restriction appears superior to changes in diet alone.

Obesity is strongly correlated with insulin resistance and both of these conditions result in pro-atherogenic changes in plasma lipoproteins, characterized by higher levels of triglycerides, lower levels of HDL, increases in VLDL-C and LDL-C, and smaller LDL particle sizes. Stable isotope turnover studies point to increased VLDL-apoB-100 and VLDL triglyceride synthesis and secretion, related to increased flux of fatty acids to the liver from visceral adipose tissue as an underlying event. There is also evidence that obesity is associated with an increased apoC-III in VLDL, which could inhibit the lipolytic cascade from VLDL to LDL, resulting in a decline in the FCR of the IDL remnant. Higher LDL levels have been related to a decreased FCR. All of these changes can account for the higher plasma levels of the proatherogenic lipoproteins. The lower levels of HDL in obesity appear to be because of an increased FCR, possibly owing to increased triglyceride content.

Gender differences with respect to the dyslipidemia of obesity are beginning to emerge from kinetic studies. While obesity is associated with higher TG levels in both men and women, an increased production rate appears responsible in men while decreased clearance is more common in women. Further studies are needed to confirm these conclusions. There may also be differences between ethnic groups, another area needing more research.

With respect to fat metabolism, although hepatic TG synthesis is increased in obese individuals, de novo lipogenesis in adipose tissue and liver constitute such a small percentage of total body lipogenesis that this process cannot account for obesity. Moreover, obesity is not related to a primary defect in lipolysis during fasting, although abdominal adipose tissue is less sensitive to epinephrine-induced lipolysis. The extent of obesity may be limited by increasing oxidation, rather than storage, of exogenous fatty acids. After gastric by-pass surgery in morbidly obese individuals, weight regain is associated with greater storage of fatty acids in adipose tissue.

Fatty acids can be made from carbohydrate as well as from dietary protein. Studies of carbohydrate metabolism in obesity using stable isotopes have revealed no change in overall endogenous glucose production because glycogenolysis is decreased while gluconeogenesis is increased. As obesity increases, the incidence of impaired glucose tolerance and of frank diabetes also increases.

Animal models of obesity and studies of the neuroendocrine regulation of appetite are beginning to unravel the human behavioral patterns of overeating and underexercising which have led to an increasing prevalence of obesity around the world, which paradoxically co-exists with undernutrition and malnutrition in many countries.

\section{REFERENCES}

Ahima RS, Flier JS. 2000. Adipose tissue as an endocrine organ. Trends Endocrinol Metab 11:327-332.

Albu J, Shur M, Curi M, Murphy L, Heymsfield SB, Pisunyer FX. 1997. Resting metabolic rate in obese, premenopausal black women. Am J Clin Nutr 66:531-538.

Ang BC, Halliday D, Powell-Tuck J. 1995. Whole-body protein turnover in response to hyperinsulinemia in humans postabsorptively with $\left[{ }^{15} \mathrm{~N}\right]$ glycine as tracer. Am J Clin Nutr 61:1062-1066.

Aston FW. 1919. The distribution of intensity along the positive ray parabolas of atoms and molecules of hydrogen and its possible explanation. Proc Camb Philos Soc 19:317.

Aston FW. 1942. Mass spectra and isotopes. Green, New York: Longmans.

Bachman ES, Dillon H, Zhang C-Y, Cinti S, Bianco AC, Kobilka BK, Lowell BB. 2002. BAR signaling required for diet-induved thermogenesis and obesity resistance. Science 297:843-845.

Battistini N, Virgili F, Severi S, Brambilla P, Manzoni P, Beccaria L, Chiumello G. 1995. Relative expansion of extracellular water in obese vs normal children. J Appl Physiol 79:94-96.

Baumgartner RN, Heymsfield SB, Lichtman S, Wang J, Pierson RN. 1991. Body-composition in elderly people-Effect of criterion estimates on predictive equations. Am J Clin Nutr 53:1345-1353.

Beylot N, Peroni O, Diraison F, Large V. 1997. In vivo studies of intrahepatic metabolic pathways. Diabetes Metab 23:251-257.

Black AE, Coward WA, Cole TJ, Prentice AM. 1996. Human energy expenditure in affluent societies: An analysis of 574 doubly-labelled water measurements. Eur J Clin Nutr 50:72-92. 
Brand WA. 1996. High precision isotope ratio monitoring techniques in mass spectrometry. J Mass Spectrom 31:225-235.

Brenna JT. 1997. Use of stable isotopes to study fatty acid and lipoprotein metabolism in man. Prostagland Leukotriene Essent Fat Acid 57:467472.

Brenna JT, Corso TN, Tobias HJ, Caimi RJ. 1997. High-precision continuousflow isotope ratio mass spectrometry. Mass Spec Rev 16:227.

Brozek J, Anderson JT, Keys A, Grande F. 1963. Densitometric analysis of body composition revision of some quantitative assumptions. Ann NY Acad Sci 110:113-140.

Bruce AC, McNurlan MA, McHardy KC, Broom J, Buchanan KD, Calder AG, Milne E, McGaw BA, Garlick PJ, James WP. 1990. Nutrient oxidation patterns and protein metabolism in lean and obese subjects. Int J Obes 14:631-646.

Caballero B, Finer N, Wurtman RJ. 1988. Plasma amino acids and insulin levels in obesity: Response to carbohydrate intake and tryptophan supplements. Metab lin Expt 37:672-676.

Caballero B, Wurtman RJ. 1991. Differential effects of insulin resistance on leucine and glucose kinetics in obesity. Metab Clin Expt 40:51-58.

Cavagnini F, Giorgino F, Seidell J, Van Gaal L. 2002. Obesity. J Endocrinol Invest 25(10): VI

Cella LK, Van Cauter E, Schoeller DA. 1995. Effect of meal timing on diurnal rhythm of human cholesterol synthesis. Am J Physiol 269:E878-E883.

Chan DC, Watts GF, Barrett PH. 2003. Comparison of intraperitoneal and posterior subcutaneous abdominal adipose tissue compartments as predictors of VLDL apolipoprotein B-100 kinetics in overweight/obese men. Diabetes Obes Metab 5:202-206.

Chan DC, Watts GF, Barrett PH, Mamo JCL, Redgrave TG. 2002a. Markers of triglyceride-rich lipoprotein remnant metabolism in visceral obesity. Clin Chem 48:278-283.

Chan DC, Watts GF, Redgrave TG, Mori TA, Barrett PH. 2002b. Apolipoprotein B-100 kinetics in visceral obesity: Associations with plasma apolipoprotein C-III concentration. Metab Clin Expt 51:10411046.

Chan DC, Watts GF, Barrett PH, Mori TA, Beilin LJ, Redgrave TG. 2002c. Mechanism of action of a 3-hydroxy-3-methylglutarylcoenzyme A reductase inhibitor on apolipoprotein B-100 kinetics in visceral obesity. J Clin Endocrinol Metab 87:2283-2289.

Chatzidakis C, Lazarus DD, Stein TP. 1994. Substrate cycling in lean and obese Zucker rats. Int J Obes Relat Metab Disord 18:287-293.

Chumlea WC, Guo SS, Zeller CM, Reo NV, Siervogel RM. 1999. Total body water data for white adults 18 to 64 years of age: The Fels Longitudinal Study. Kid Int 56:244-252.

Chumlea WC, Guo SS, Zeller CM, Reo NV, Baumgartner RN, Garry PJ, Wang J, Pierson RN, Heymsfield SB, Siervogel RM. 2001. Total body water reference values and prediction equations for adults. Kid Int 59:2250-2258

Cobelli C, Toffolo G, Bier DM, Nosadini R. 1987. Models to interpret kinetic data in stable isotope tracer studies. Am J Physiol 253:E551-E564.

Coggan AR. 1999. Use of stable isotopes to study carbohydrate and fat metabolism at the whole-body level. Proc Nutr Soc 58:953-961.

Cohen P, Zhao C, Montez JM, Rohani SC, Feinstein P, Mombaerts P, Friedman JM. 2001. Selective deletion of leptin receptor in neurons leads to obesity. J Clin Invest 108:1113-1121.

Cohen P, Miyazaki M, Socci ND, Hagge-Greenberg A, Liedtke W, Soukas AA, Sharma R, Hudgins LC, Ntambi JM, Friedman JM. 2002. Role for stearoyl-CoA desaturase-1 in leptin-mediated weight loss. Science 297:240-243.

Cohn JS, Wagner DA, Cohn SD, Millar JS, Schaefer EJ. 1990. Measurement of very low density and low density lipoprotein apolipoprotein (Apo) B100 and high density lipoprotein Apo A-I production in human subjects using deuterated leucine. Effect of fasting and feeding. J Clin Invest 85:804-811.
Coplen TB. 1988. Normalization of oxygen and hydrogen isotope data. Chem Geol 72:293-297.

Coplen TB, Wildman JD, Chen J. 1991. Improvements in the gaseoushydrogen water equilibration technique for hydrogen isotope ratio analysis. Anal Chem 63:910-912.

Couillard C, Bergeron N, Pascot A, Almeras N, Bergeron J, Tremblay Prud'homme D, Despres JP. 2002. Evidence for impaired lipolysis in abdominally obese men: Postprandial study of apolipoprotein B-48 and B-100-containing lipoproteins. Am J Clin Nutr 76:299-300.

Craig H. 1953. The geochemistry of carbon isotopes. Geochim Cosmochim Acta 3:53-92.

Cryer DR, Matsushima T, Marsh JB, Yudkoff M, Coates PM, Cortner JA. 1986. Direct measurement of apolipoprotein B synthesis in human VLDL using stable isotopes and mass spectrometry. J Lipid Res 27: 508-516.

Cummings MH, Watts GF, Pal C, Umpleby M, Hennessy TR, Naoumova R, Sönksen PH. 1995. Increased hepatic secretion of very-low-density lipoprotein apolipoprotein B 100 in obesity: A stable isotope study. Clin Sci 88:225-233.

Dallal Ge, Roberts SB. 1991. DLW- A computer program for the calculation of total energy expenditure in doubly labeled water $\left({ }^{2} \mathrm{H}_{2} \mathrm{O}\right)-\left(\mathrm{H}_{2}{ }^{18} \mathrm{O}\right)$. Studies Comput Biomed Res 24:143-151.

Das SK, Roberts SB, Kehayias JJ, Wang J, Hsu GLK, Shikora SA, Saltzman E, McCrory MA. 2003. Body composition assessment in extreme obesity and after massive weight loss induced by gastric bypass surgery. Am J Physiol Endocrinol Metab 284:E1080-E1088.

DeLorenzo A, Andreoli A, Matthie J, Withers P. 1997. Predicting body cell mass with bioimpedance by using theoretical methods: A technological review. J Appl Physiol 82:1542-1558.

Delzenne N, Ferre P, Beylot M, Daubioul C, Declercq B, Diraison F, Dugail I, Foufelle F, Foretz N, Mace K, Reimer R, Palmer G, Rutter G, Tavare J, Van Loo J, Vidal H. 2001. Study of the regulation by nutrients of the expression of genes involved in lipogenesis and obesity in humans and animals. Nutr Metab Cardiovasc Dis 11:S118-S121.

Dempster AJ. 1918. A new method of positive ray analysis. Phys Rev 11:316-324.

Dempster P, Aitkens S. 1995. A new air displacement method for the determination of human body composition. Med Sci Sports Exerc 27: $1692-1697$.

DiBuono M, Jones PJ, Beaumier L, Wykes LJ. 2000. Comparison of deuterium incorporation and mass isotopomer distribution analysis for measurement of human cholesterol biosynthesis. J Lipid Res 41:15161523.

Doi T, Liu M, Seeley RJ, Woods SC, Tso P. 2001. Effect of leptin on intestinal apolipoprotein A-IV in response to lipid feeding. Am J Physiol Regul Integr Comp Physiol 281:R753-R759.

Dulloo AG. 2002. A sympathetic defense against obesity. Science 297:780781 .

Duvillard L, Verges B, Gambert P. 1998, Development of compartmental models in stable-isotope experiments-Application to lipid metabolism. Arterio ThrombVasc Biol 18:853-860.

Ebbeling CB, Rodriguez NR. 1998. Effects of reduced energy intake on protein utilization in obese children. Metab Clin Expt 47:1434-1439.

Edwards PA, Kast HRL, Anisfeld AM. 2002. BAREing it all: The adoption of LXR and FXR and their roles in lipid homoeostasis. J Lipid Res 43: $2-12$.

Egusa G, Beltz WF, Grundy SM, Howard BV. 1985. Influence of obesity on the metabolism of apolipoprotein B in humans. J Clin Invest 76: 596-603.

Ekelund U, Aman J, Yngve A, Renman C, Westerterp K, Sjostrom M. 2002. Physical activity but not energy expenditure is reduced in obese adolescents: A case-control study. Am J Clin Nutr 76(5):935-941.

Ellis KJ. 2000. Human body composition: In vivo methods. Physiol Rev 80:649-680. 
Emken EA. 2001. Stable isotope approaches, applications, and issues related to polyunsaturated fatty acid metabolism studies. Lipids 36 : 965-973.

Faraj M, Jones P, Sniderman AD, Cianflone K. 2001. Enhanced dietary fat clearance in postobese women. J Lipid Res 42:571-580.

Fields DA, Goran MI, McCrory MA. 2002. Body composition assessment via air-displacement plethysmography in adults and children: A review. Am J Clin Nutr 75:453-467.

Flegal KM, Carroll MD, Ogden CL, Johnson CL. 2002. Prevalence and trends in obesity among US adults, 1999-2000. JAMA 288:1723-1727.

Fogelholm M, Lichtenbelt WV. 1997. Comparison of body composition methods: A literature analysis. Eur J Clin Nutr 51:495-503.

Forslund AH. 1998. Evaluation of modified multicompartment models to calculate body composition in healthy males. Appl Rad Isotopes 49: 599-601.

Foster DM, Barrett PHR, Toffolo G, Beltz WF, Cobelli C. 1993. Estimating the fractional synthetic rate of plasma apolipoproteins and lipids from stable isotope data. J Lipid Res 34:2193-2206.

Gallagher D, Kovera AJ, Clay-Williams G, Agin D, Leone P, Albu J, Matthews DE, Heymsfield SB. 2000. Weight loss in postmenopausal obesity: No adverse alterations in body composition and protein metabolism. Am J Physiol Endocrinol Metab 279:E124-E131.

Garlick PJ, Clugston GA, Waterlow JC. 1980. Influence of low energy diets on whole body protein turnover in obese subjects. Am J Physiol 238: E235-E244.

Gonfiantini R. 1978. Standards for stable isotope measurements in natural compounds. Nature 271:534-536.

Goran MI, Poehlman Et, Danforth E, Nair KS. 1994. Comparison of body fat estimates derived from underwater weight and total body water. Int $\mathbf{J}$ Obesity 18:622-626.

Gougeon R, Pencharz PB, Marliss EB. 1995. Whole body protein turnover in obese subjects during two very low energy diets of differing amino acid composition. Int J Obes Relat Metab Disord 19:739-748.

Gougeon R, Hoffer LJ, Pencharz PB, Marliss EB. 1992. Protein metabolism in obese subjects during a very-low-energy diet. Am J Clin Nutr 56: 249S-254S.

Graziani MS, Zanolla L, Righetti G, Marchetti C, Zanotto G, Lupo A. 1994. Distribution of CII and CIII peptides in lipoprotein classes: Methods and clinical significance. Clin Chem 40:240-244.

Grob K. 1985. Film thickness required of the stationary phase in the separation column when using large retention gaps in capillary gaschromatography. J Chromatog 328:55-61.

Guo ZK, Cella LK, Baum C, Ravussin E, Schoeller DA. 2000. De novo lipogenesis in adipose tissue of lean and obese women: Application of deuterated water and isotope ratio mass spectrometry. Int J Obes Relat Metab Disord 24:932-937.

Hellerstein MK. 1996. Synthesis of fat in response to alterations in diet: Insights from new stable isotope methodologies. Lipids 31:S117-S125.

Hoffer LJ, Forse RA. 1990. Protein metabolic effects of a prolonged fast and hypocaloric refeeding. Am J Physiol 258:E832-E840.

Hoffer LJ, Bistrian BR, Young VR, Blackburn GL, Matthews DE. 1984. Metabolic effects of very low calorie weight reduction diets. J Clin Invest 73:750-758.

Hoffer LJ, Yang RD, Matthews DE, Bistrian BR, Bier DM, Young VR. 1988. Alanine flux in obese and healthy humans as evaluated by ${ }^{15} \mathrm{~N}$ - and ${ }^{2} \mathrm{H}_{3}$ labeled alanine. Am J Clin Nutr 18:1010-1014.

Hoffman DJ, Roberts SB, Martins PA, de Nascimento C, Sawaya AL. 2000. Evidence for impaired regulation of energy intake in nutritionally stunted children from the shantytowns of Sao Paulo, Brazil. J Nutr 130(9):2265-2270.

Hopple JA, Hannon JE, Coplen TB. 1998. Comparison of two stable hydrogen isotope-ratio measurement techniques on antarctic surface-water and ice samples. Chem Geol 152:321-323.
Horita J. 1988. Hydrogen isotope analysis of natural-waters using an ${ }^{2} \mathrm{H}$ water equilibration method-A special implication to brines. Chem Geol 72: 89-94.

Horowitz JF, Klein S. 2000. Whole body and abdominal lipolytic sensitivity to epinephrine is suppressed in upper body obese women. Am J Physiol Endocrinol 278:E1144-E1152.

IAEA-TECDOC-825. 1993. Reference and intercomparison materials for stable isotopes of light elements. International Atomic Energy Agency.

Institute of Medicine. 2002. Dietary reference intakes: Energy, carbohydrate, fiber, fat, fatty acids, cholesterol, protein, and amino acids. Washington, D.C.: The National Academy Press.

James AT. 1970. The development of gas-liquid chromatography. Biochem Soc Symp 30:199-211.

Jequier E. 2002. Leptin signaling, adiposity, and energy balance. Ann NY Acad Sci 967:379-388.

Kehayias JJ, Fiatarone MA, Zhuang H, Roubenoff R. 1997. Total body potassium and body fat: Relevance to aging. Am J Clin Nutr 66:904910.

Klein S, Young VR, Blackburnm GL, Bistrian BR, Wolfe RR. 1988. The impact of body composition on the regulation of lipolysis during shortterm fasting. J Am Coll Nutr 7:77-84.

Koletzko B, Demmelmair H, Hartl W, Kinmdermann A, Koletzko S, Sauerwald T, Szitanyi P. 1998. The use of stable isotope techniques for nutritional and metabolic research in pediatrics. Early Hum Dev 53:S77-S97.

Lamon-Fava S, Wilson PWF, Schaefer EJ. 1996. Impact of body mass index on coronary heart disease risk factors in men and women-The Framingham Offspring Study. Arterio Thromb Vasc Biol 16:15091515.

Landau BR. 1999. Glycerol production and utilization measured using stable isotopes. Proc Nutr Soc 58:973-978.

Lee WN, Bassilian S, Ajie HO, Schoeller DA, Edmond J, Bergner EA, Byerley LO. 1994. In vivo measurement of fatty acids and cholesterol synthesis using $\mathrm{D}_{2} \mathrm{O}$ and mass isotopomer analysis. Am J Physiol 266:E699-E708.

Leis HJ, Fauler G, Windischhofer W. 1998. Stable isotope labeled target compounds: Preparation and use as internal standards in quantitative mass spectrometry. Curr Org Chem 2:131-144.

Li WW, Dammerman MM, Smith JD, Metzger S, Breslow JL, Leff T. 1995. Common genetic variation in the promoter of the human apo CIII gene abolishes regulation by insulin and may contribute to hypertriglyceridemia. J Clin Invest 96:2601-2605.

Lichtenstein AH, Cohn JS, Hachey DL, Millar JS, Ordovas JM, Schaefer EJ. 1990. Comparison of deuterated leucine, valine, and lysine in the measurement of human apolipoprotein A-I and B-100 kinetics. J Lipid Res 31:1693-1701.

Lucidi P, Parlanti N, Santeusanio F, DeFeo P. 2002. Sort-term treatment with low doses of recombinant human GH stimulates lipolysis in visceral obese men. J Clin Endocrinol Metab 87:3105-3109.

Maffeis C, Armellini F, Tato L, Schutz Y. 1999. Fat oxidation and adiposity in prepubertal children: Exogenous versus endogenous fat utilization. J Clin Endocrinol Metab 84:654-658.

Marchini JS, Lambertini CR, Ferriolli E, Dutra de Oliveira JE. 2001. Obese women on low energy rice and bean diet: Effects of leucine, arginine, or glycine supplementation on protein turnover. Braz J Med Biol Res 34: $1277-1283$.

Marques-Lopes I, Ansorena D, Astiasaran I, Forga L, Martinez JA. 2001. Postprandial de novo lipogenesis and metabolic changes induced by a high-carbohydrate, low-fat meal in lean and overweight men. Am J Clin Nutr 73:253-261.

Marsh JB, Welty FK, Schaefer EJ. 2000. Stable isotope turnover of apolipoproteins of high-density lipoproteins in humans. Curr Opin Lipidol 11:261-266. 
Marsh JB, Diffenderfer MR. 1991. Use of $\left[{ }^{15} \mathrm{~N}\right]$ glycine in the measurement of apolipoprotein B synthesis in perfused rat liver. J Lipid Res 32:2019-2024.

Marsh JB, Welty FK, Lichtenstein AH, Lamon-Fava S, Schaefer EJ. 2002. Apolipoprotein B metabolism in humans: Studies with stable isotopelabeled amino acid precursors. Atherosclerosis 162:227-244.

Matthews DE, Gilker CD. 1995, Impact of ${ }^{2} \mathrm{H}$ and ${ }^{18} \mathrm{O}$ pool size determinations on the calculation of total energy expenditure. Obes Res 3:S121-S129.

May WE, Rumble J. 2001. Report of Investigation for Reference Materials 8535, 8536, 8537, National Institute of Standards and Technology.

Mazariegos M, Kral JG, Wang J, Waki M, Heymsfield SB, Pierson RN Jr, Thornton JC, Yasumura S. 1992. Body composition and surgical treatment of obesity-Effects of weight loss on fluid distribution. Ann Surg 216:69-73.

McCrea JM. 1950. On the isotope chemistry of carbonates and a paleotemperature scale. J Chem Phys 18:849-857.

McGloin AF, Livingstone MBE, Greene LC, Webb SE, Gibson JMA, Jebb SA, Cole TJ, Coward WA, Wright A, Prentice AM. 2002. Energy and fat intake in obese and lean children at varying risk of obesity. Int J Obes 26(2):200-207.

Meier-Augenstein W. 2002. Stable isotope analysis of fatty acids by gas chromatography-isotope ratio mass spectrometry. Analyt Chim Acta 465:63-79.

Mittendorfer B, Patterson BW, Klein S. 2003a. Effect of sex and obesity on very low density lipoprotein triacylglycerol kinetics. Am J Clin Nutr 77:573-579.

Mittendorfer B, Patterson BW, Klein S. 2003b. Effect of weight loss on VLDL triglyceride and apolipoprotein B-100 kinetics in women with abdominal obesity. Am J Physiol Endocrinol Metab 284:E549-E556.

Miyazaki N, Kim YC, Gray-Keller MP, Attie AD, Ntambi JM. 2000. The biosynthesis of hepatic cholesterol esters and triglycerides is impaired in mice with a disruption of the gene for stearoyl-CoA desaturase 1. J Biol Chem 275:30132-30138.

Muller C, Assimacopoulos-Jeannet F, Mosimann F, Schneiter P, Riou JP, Pachiaudi G, Felber JP, Jequier E, Jeanrenaus B, Tappy L. 1997. Endogenous glucose production gluconeogenesis and liver glycogen concentration in obese non-diabetic patients. Diabetologia 40:463-468.

Munsch S. 2002. Epidemiology of obesity. Verhaltenstherapie 12:278-287.

National Vital Statistics Report. 2002. Deaths and percent of total deaths for the 10 leading causes of death: United States, 1999-2000:50 (16).

Nier A. 1947. A mass spectrometer for isotope and gas analysis. Rev Sci Instrum 18:398-411.

Ntambi JM, Miyazaki M, Stoehr JP, Lan H, Kendziorski CM, Yandell BS, Song Y, Cohen P, Friedman JM, Attie AD. 2002. Loss of stearoyl-CoA desaturase-1 function protects mice against adiposity. Proc Natl Acad Sci USA 99:11482-11486.

Oi Y, Okuda T, Koh H, Waki M, Kurata M, Nambu S. 1987. Effects of low energy diets on protein metabolism studies with $\left[{ }^{15} \mathrm{~N}\right]$ glycine in obese patients. J Nutr Sci Vitaminol 33:227-237.

Ougerram K, Krempf M, Naugeais C, Naugere P, Darmaun D, Magot T. 2002. A new labeling approach using stable isotopes to study in vivo plasma cholesterol metabolism in humans. Metab Clin Expt 51:5-11.

Paquot N, Schneiter P, Scheen AJ, Lefebvre PJ, Tappy L. 2000. Assessment of postprandial hepatic glycogen synthesis from uridine diphosphoglucose kinetics in obese and lean non-diabetic subjects. Int J Obes Relat Metab Disord 24:1297-1302.

Parker RS, Brenna JT, Swanson JE, Goodman KJ, Marmor B. 1997. Assessing metabolism of beta- $\left[{ }^{13} \mathrm{C}\right]$-carotene using high-precision isotope ratio mass spectrometry. Vitamins and Coenzymes, Pt L. Meth Enzymol 282:130-140.

Pencharz PB, Clarke R, Archibald EH, Vaisman N. 1988. The effects of a weight reducing diet on the nitrogen metabolism of obese adolescents. Can J Physiol Pharm 66:1469-1474.
Pietrobelli A, Formica C, Wang ZM, Heymsfield SB. 1996. Dual-energy Xray absorptiometry body composition model: Review of physical concepts. Am J Physiol Endocrinol Metab 271:E941-E951.

Pont F, Duvillard L, Verges B, Gambert P. 1998. Development of compartmental models in stable-isotope experiments-Application to lipid metabolism. Arterioscler Thromb Vasc Biol 18:853-860.

Pont F, Duvillard L, Florentin E, Gambert P, Verges B. 2002a. Early kinetic abnormalities of apoB-containing lipoproteins in insulin-resistant women with abdominal obesity. Arterioscler Thromb Vasc Biol 22: 1726-1732.

Pont F, Duvillard L, Florentin E, Gambert P, Verges B. 2002b. Highdensity lipoprotein A-I kinetics in obese insulin-resistant patients. An in vivo stable isotope study. Int J Obes Relat Metab Disord 26:11511158.

Popkin BM, Doak CM. 1998. The obesity epidemic is a worldwide phenomenon. Nutr Rev 56:106-114.

Prentice AM, Black AE, Coward WA, Cole TJ. 1996. Energy expenditure in overweight and obese adults in affluent societies: An analysis of 319 doubly-labelled water measurements. Eur J Clin Nutr 50:93-97.

Prosser SJ, Scrimgeour CM. 1995. High-Precision determination of ${ }^{2} \mathrm{H} /{ }^{1} \mathrm{H}$ in $\mathrm{H}-2$ and $\mathrm{H}_{2} \mathrm{O}$ by continuous-flow isotope ratio mass-spectrometry. Anal Chem 67(13):1992-1997.

Racette SB, Schoeller DA, Luke Ah, Shay K, Hnilicka J, Kushner RF. 1994. Relative dilution spaces of ${ }^{2} \mathrm{H}$-labeled and ${ }^{18} \mathrm{O}$-labeled water in humans. Amer J Physiol Endocrinol Metab 267:E585-E590.

Ragunathan N, Krock KA, Klawun C, Sasaki TA, Wilkins CL. 1999. Gas chromatography with spectroscopic detectors. J Chromatog 856:349397.

Ravussin E, Doerner A, Acheson KJ, Pahud P, Arnaud MJ, Jequier E. 1980. Carbohydrate utilization in obese subjects after an oral load of $100 \mathrm{~g}$ naturally-labeled $\left[{ }^{13} \mathrm{C}\right]$ glucose. Br J Nutr 43:281-288

Rhee SK, Kayani AJ, Ciszek A, Brenna JT. 1997. Desaturation and interconversion of dietary stearic and palmitic acids in human plasma and lipoproteins. Am J Clin Nutr 65:451-458

Riches FM, Watts GF, Naoumova RP, Kelly JM, Croft KD, Thompson GR. 1998. Hepatic secretion of very-low-density lipoprotein apolipoprotein B-100 studied with a stable isotope technique in men with visceral obesity. Int J Obes Relat Metab Disord 22:414-423.

Roberts SB, Dietz W, Sharp T, Dallal GE, Hill JO. 1995. Multiple laboratory comparison of the doubly labeled water technique. Obes Res 3 : S3-S13.

Roubenoff R, Hughes VA, Dallal GE, Nelson ME, Morganti C, Kehayias JJ, Singh MAF, Roberts S. 2000. The effect of gender and body composition method on the apparent decline in lean mass-adjusted resting metabolic rate with age. J Gerontol A Biol Sci Med Sci 55: M757-M760.

Ryhage R. 1964. Use of mass spectrometer as detector + analyzer for effluents emerging from high temperature gas-liquid chromatography columns. Anal Chem 36:759.

SAAM II. 1994. User Guide. Seattle, Wash: SAAM Institute, Inc.

Salam WH, Wilcox HG, Heimberg M. 1988. Effects of oleic acid on the biosynthesis of lipoprotein apoproteins and distribution into the verylow-density lipoprotein by the isolated perfused rat liver. Biochem $\mathrm{J}$ 251:809-816.

Schoeller DA. 1990. How accurate is self-reported dietary energy intake? Nutr Rev 48:373-379.

Schoeller DA, Bandini LG, Dietz WH. 1990. Inaccuracies in self-reported intake identified by comparison with the doubly labelled water method. Can J Phys Pharm 68:941-949.

Schoeller DA, Taylor PB, Shay K. 1995. Analytic requirements for the doubly labeled water method. Obesity Research 3(Suppl.):15-20.

Schoeller DA, Vansanten E. 1982. Measurement of energy expenditure in humans by doubly labeled water method. J Appl Physiol 53:955-959. 
Schoeller DA, Vansanten E, Peterson DW, Dietz W, Jaspan J, Klein PD. 1980, Total body water measurement in humans with ${ }^{18} \mathrm{O}$ and ${ }^{2} \mathrm{H}$-labeled water. Am J Clin Nutr 33:2686-2693.

Schoeller DA, VanSanten E, Peterson DW, Dietz W, Jaspan J, Klein PD. 1980. Total body water measurement in humans with ${ }^{18} \mathrm{O}$ and ${ }^{2} \mathrm{H}$ labeled water. Am J Clin Nutr 44:291-298.

Schoeller DA, Ravussin E, Schutz Y, Acheson KJ, Baertschi P, Jequier E. 1986. Energy expenditure by doubly-labeled water- Validation in humans and proposed calculation. Am J Physiol 250:R823-R830.

Schoeller DA, Colligan AS, Shriver T, Avak H, Bartok-Olson C. 2000. Use of an automated chromium reduction system for hydrogen isotope ratio analysis of physiological fluids applied to doubly labeled water analysis. J Mass Spectrom 35:1128-1132.

Schutz Y, Rueda-Maza CM, Zaffanello M, Maffeis C. 1999. Whole-body protein turnover and resting energy expenditure in obese, prepubertal children. Am J Clin Nutr 69:857-862.

Seman LJ, McNamara JR, Schaefer EJ. 1999. Lp(a), homocysteine, and remnant-like particles: Emerging risk factors. Curr Opin Cardiol 14: $186-191$.

Serdula MK, Ivery D, Freedman DS, Williamson DF, Byers T. 1993. Do obese children become obese adults? A review of the literature. Prev Med 22:167-177.

Shen W, Wang ZM, Punyanita M, Lei JB, Sinav A, Kral JG, Imielinska C, Ross R, Heymsfield SB. 2003. Adipose tissue quantification by imaging methods: A proposed classification. Obes Res 11:5-16.

Shuldiner AR, Yang R, Gong D-W. 2001. Resistin, obesity, and insulin resistance-The emerging role of the adipocyte as an endocrine organ. N Engl J Med 345:1345-1346.

Siri P, Candela N, Zhang YL, Ko C, Eusufzai S, Ginsberg HN, Huang LS. 2001. Post-transcriptional stimulation of the assembly and secretion of triglyceride-rich apolipoprotein B lipoproteins in a mouse with selective deficiency of brown adipose tissue, obesity, and insulin resistance. J Biol Chem 276:46064-46072.

Sonko BJ, Miller LV, Jones RH, Donnelly JE, Jacobsen DJ, Hill JO, Fennessey PV. 2003. Multi-point estimation of total energy expenditure: a comparison between zinc-reduction and platinum-equilibration methodologies. Anal Biochem 323:211-217.

Speakman JR, Nair KS, Goran MI. 1993. Revised equations for calculating $\mathrm{CO}_{2}$ production from doubly-labeled water in humans. Am J Physiol 264:E912-E917.

Stunff CL, Bougneres PF. 1996. Alterations of plasma lactate and glucose metabolism in obese children. Am J Physiol 271:E814-E820.

Sumner AE, Falkner B, Diffenderfer MR, Barrett PHR, Marsh JB. 1999. A study of the metabolism of apolipoprotein $\mathrm{B} 100$ in relation to insulin resistance in African American males. Proc Soc Exp Biol Med 4:352-360.

Sun Z, Lichtenstein AH, Dolnikowski GG, Welty FK, Schaefer EJ. 2001. Human apolipoprotein A-IV metabolism within triglyceride-rich lipoproteins and plasma. Atherosclerosis 156:363-372.

Thielecke F, Brand W, Noack R. 1998. Hydrogen isotope determination for small-size water samples using an equilibration technique. J Mass Spectrom 33:342-345.

Thielecke F, Noack R. 1997. Evaluation of an automated equilibration technique for deuterium/hydrogen isotope ratio measurements with respect to assessing total energy expenditure by the doubly labelled water method. J Mass Spectrom 32:323-327.

Thomson JJ. 1913. Rays of positive electricity and their application to chemical analyses. Green, New York: Longmans.

Thomson JJ. 1921. "Isotopes"-Containing papers of a mathematical and physical character. Proc. Royal Soc. London, Series A 99:87-104.

Tso P, Liu M, Kalogeris TJ, Thomson ABR. 2001. The role of apolipoprotein A-IV in the regulation of food intake. Annu Rev Nutr 21:231-254.

Van Itallie TB. 1985. Health implications of overweight and obesity in the United States. Ann Intern Med 103:983-988.
Wagenmakers AJM. 1999. Tracers to investigate protein and amino acid metabolism in human subjects. Proc Nutr Soc 58:987-1000.

Wajchenberg BL. 2001. Subcutaneous and visceral adipose tissue: Their relation to the metabolic syndrome. Endocrin Rev 21:697-738.

Waki M, Kral JG, Mazariegos M, Wang J, Pierson RN, Heymsfield SB. 1991. Relative expansion of extracellular fluid in obese vs nonobese women. Am J Physiol 261(Pt. 1):E199-E203.

Wang Z, Pierson RN Jr, Heymsfield SB. 1992. The five-level model: A new approach to organizing body-composition research. Am J Clin Nutr 56: $19-28$.

Wang ZM, Durenberg P, Guo SS, Pietrobelli A, Wang J, Pierson RN Jr, Heymsfield SB. 1998. Six-compartment body composition model: Inter-method comparisons of total body fat measurements. Int J Obes Relat Metab 22:329-337.

Wang ZM, Deurenberg P, Wang W, Pietrobelli A, Baumgartner RN, Heymsfield SB. 1999a. Hydration of fat-free body mass: New physiological modeling approach. Am J Physiol 276:E995-E1003.

Wang ZM, Deurenberg P, Pietrobelli A, Baumgartner RN, Heymsfield SB. 1999b. Hydration of fat-free body mass: Review and critique of a classic body composition constant. Am J Clin Nutr 69:833-841.

Watson JT. 1997. Introduction to mass spectrometry, 3rd edn. NY: Raven Press.

Watson JT, Biemann K. 1964. High-resolution mass spectra of compounds emerging from a gas chromatograph. Anal Chem 36:1135.

Watts GF, Chan DCF, Barrett PHR, Martins IJ, Redgrave TG. 2001. Preliminary experience with a new stable isotope breath test for chylomicron remnant metabolism: A study in central obesity. Clin Sci 101:683-690.

Watts GF, Chan DC, Barrett PH, Susekov AV, Hua J, Song S. 2003. Fat compartments and apolipoprotein B-100 kinetics in overweight-obese men. Obes Res 11:152-159.

Welty FK, Lichtenstein AH, Barrett PHR, Dolnikowski GG, Schaefer EJ. 1999. Human apolipoprotein (Apo) B-48 and apoB-100 kinetics with stable isotopes. Arterioscler Thromb Vasc Biol 19:2966-2974.

WHO. 1997. Obesity: Preventing and managing the global epidemic. Geneva: World Health Organization.

Withers RT, Laforgia J, Heymsfield SB. 1999. Critical appraisal of the estimation of body composition via two, three, and four-compartment models. Am J Hum Biol 11:175-185.

Wong WW, Lee LS, Klein PD. 1987. Deuterium and ${ }^{18} \mathrm{O}$ measurements on microliter samples of urine, plasma, saliva, and human milk. Am J Clin Nutr 45:905-913.

Wong WW, Klein PD. 1986. A review of techniques for the preparation of biological samples for mass spectrometric measurements of ${ }^{2} \mathrm{H}-{ }^{1} \mathrm{H}$ and ${ }^{18} \mathrm{O}-{ }^{16} \mathrm{O}$ isotope ratios. Mass Spec Rev 5:313-342.

Wong WW, Sheng H, Morkeberg JC, Kosanovich JL, Clarke LL, Klein PD. 1989. Measurement of extracellular water volume by bromide ion chromatography. Am J Clin Nutr 50:1290-1294.

Wong WW, Clarke LL, Llaurador M, Klein PD. 1992. A new zinc product for the reduction of water in physiological fluids to hydrogen gas for ${ }^{2} \mathrm{H} /{ }^{1} \mathrm{H}$ isotope ratio measurements. European J Clin Nutr 46: 69-71.

World Health Organization. 1995. Measuring obesity. Classification and description of anthropometric data. Copenhagen, Denmark: WHO.

Yao M, Roberts SB, Ma G, Pan H, McCrory MA. 2002. Field methods for body composition assessment are valid in healthy Chinese Adults. J Nutr 132:310-317.

Young VR, Ajami A. 1999. The Rudolf Schoenheimer Centenary Lecture. Isotopes in nutrition research. Proc Nutr Soc 58:15-32.

Zhang CY, Baffy G, Perret P, Krauss S, Peroni O, Grujic D, Hagen T, VidalPuig AJ, Boss O, Kim YB. 2001. Uncoupling protein-2 negatively regulates insulin secretion and is a major link between obesity, cell dysfunction, and type 2 diabetes. Cell 105:745-755. 
Gregory G. Dolnikowski received his Ph.D. from Michigan State University with J. Throck Watson in the fields of isotope ratio mass spectrometry and ion/molecule reactions. He held a post-doctoral fellowship at the University of Warwick (U.K.) with K. R. Jennings in the fields of ion/molecule reactions and instrument development. He held a second postdoctoral fellowship at the University of Nebraska-Lincoln with M. L. Gross in the field of DNA-Adducts with PAH compounds. He is presently Clinical Assistant Professor at Gerald J. and Dorothy R. Friedman School of Nutrition Science and Policy at Tufts University, and Mass Spectrometry Laboratory Director at the Jean Mayer USDA Human Nutrition Research Center on Aging at Tufts University. The research in the mass spectrometry laboratory is focused on human nutrition and aging and includes quantification and identification of vitamins, amino acids, nucleic acids, lipids, fatty acids, retinoids, carotenoids, peptides, and proteins from food and human body fluids. These data lead to the determinations of total energy expenditure, total body water, whole-body protein turnover, vitamin metabolism and bioavailability, DNA methylation, and apolipoprotein kinetics.

Julian B. Marsh received his M.D. from the University of Pennsylvania with David L. Drabkin. He held a post-doctoral fellowship at USPHS with William C. Stadie, at University of Pennsylvania in the field of insulin action. He was a Guggenheim Fellow at the National Institute for Medical Research, London with A. T. James in the field of fatty acid metabolism. He is presently Visiting Scientist and Head of the Metabolism Section of the Atherosclerosis Research Lab, USDA-HNRCA at Tufts University and Adjunct Professor of Biochemistry at the University of Pennsylvania. He was the former chairman of the Council on Arteriosclerosis, AHA; and former editor of the Journal of Lipid Research. He now conducts collaborative research with E. J. Schaefer and others in the field of stable isotope turnover studies of apolipoproteins in individuals with renal disease.

Sai Krupa Das is currently a Postdoctoral-Clinical Nutrition Fellow at the Energy Metabolism Laboratory of the Jean Mayer USDA Human Nutrition Research Center on Aging at Tufts University and at Tufts New England Medical Center (Boston, MA). She is working on an NIH Grant (NIA) titled "Dietary energy restriction and metabolic aging in humans." She obtained her Ph.D. in Human Nutrition from Tufts University School of Nutrition Science and Policy (Boston, MA) and did her thesis work on "Energy metabolism and body composition changes in the extremely obese after bariatric (gastric bypass) surgery" under the mentorship of Professor Susan Roberts. The Energy Metabolism Laboratory explores the genetic and environmental factors that determine body composition and energy regulation, as well as quantifying optimal dietary energy requirements. Whole-body physiology studies focus on the importance of both energy intake and expenditure in determining body fat gain during adult life. Hormonal and cellular investigations are conducted to identify the underlying metabolic cause of individual differences in body composition and energy regulation. Dr. Das's specific research focuses include energy metabolism, obesity and body weight regulation in humans, and human caloric restriction.

Francine Welty received her M.D., Ph.D. from Case Western Reserve Medical School (Cleveland) with Harland G. Wood. She is presently Associate Professor of Medicine in the Division of Cardiology at Harvard Medical School. She is the Director of the Cardiovascular Care for Women Program at Beth Israel Deaconess Medical Center and Director of Preventive Cardiology and Nutrition Education. Her research is focused on the investigation of mutations associated with low LDL cholesterol, and determination of the effect of dietary soy on lipid levels on atherosclerotic markers in postmenopausal women. 